九州歯会誌 $32(3): 357 \sim 373,1978$.

\title{
下顎骨欠損における新鮮自家肋骨移植に関する実験的研究
}

九州柬科大学第 1 口腔外科学教空（指導：山田長敬教授）

安西學

昭和53年 6 月 29 日受付

(本論文の要旨は，炤和52年10月23日第22回日本口腔外科学会総会において発表した。）

\section{An Experimental Study on Bone Graft of Fresh Autogeneous \\ Rib-bone in Mandible}

By

Manabu Anzai

First Department of Oral Surgery (Director : Prof. Nagayoshi Yamada)

Kyushu Dental College, Kitakyushu, Japan

The author performed osteoectomy of the mandible on 23 adult mongrels (about a year old) and grafted fresh autogenous rib-bone. Observations by tetracycline labelling and microradio-graphy were made of the changes in the grafted bones and the original bones. Pathohistological investigations were also made of the non-decalcified and decalcified stained specimens.

The results were as follows:

1. In fluorohistological findings, tetracycline labelling of new bone was observed in the original bones, in the mandibular canal in particular, on the 5th day after grafting and in the grafted bones on the 15 th day.

On the 30th day, tetracycline labelling of new bone forming from the original bone and connected with the grafted bone was observed. Tetracycline of new bone forming from the upper parts of the resected ends of some of the grafted bones to the original bones was also observed.

From the 45 th to 60 th days, tetracycline labelling of the whole of new bone trabecula between the resected ends of the original and grafted bones was observed. On the 90th day, however, tetracycline labelling of only a single layer around the marrow spacies was observed.

2. In microradiographyic findings, calcification of the reticulum, of low radiolucency, was observed in the original bone on the 5th day after grafting and in the grafted bone on the 15th day.

On the 30th day, radiolucency of trabecula-like body, connected with the grafted bone, of new bone extending from the original bone was observed in the upper parts of the resected ends of the grafted bones. As for the new bone from the resected ends of the grafted bones to the original bones, calcification of low radiolucency was observed.

From the 45 th to 60 th days, calcification of the new bone between the original and 
the grafted bones was low. Marked difference in radiolucency was observed when compared with that of the original bone, but on the 90th day, radiolucency was about the same.

3. In non-decalcified and decalcified stained specimens, marked fibrous plasia in the mandibular canal of the mesial and distal resected ends of the original bone was observed and bone generation was also active compared with other parts. In the marrow gradual transformation to granulation tissues from the resected ends to the center was observed and replacement by granulation tissues was nearly complete on the 30th day after grafting.

On the 10th day, granulation tissues were observed in the marrow of the resected ends of the grafted bones and calcification was observed on the 15th day.

On the 20th day, new formation of bone trabecula of the grafted bones was observed and the formation progressed gradually to the center.

On the 30th day, union with the original bone was seen and formation of new bone was seen nearly to the center, although some original bone trabecula still remained.

On the 60th day, repairing processes of new bone was active. Transformation to fatty marrow and the regular arrangement of the osteocytes were seen on the 90th day.

However, the original bone trabecula was observed remaining although to a limited extent.

4. In the present experiment, osteocytes of the grafted bones did not die out completely. Rather, they seem to have some part in osteogenesis and bone union with the original bone.

\section{緒言}

顎領域における骨移植は，顎骨疾患，口腔腫場および 外傷などによる骨欠損の形態的, 機能的恢復を目的とし て行なわれている.

骨移植に関する歴史は古く，Lexer(1945) ${ }^{1 \prime}$ は，1682 年 Job-a-Meekren が 人の頭蓋骨欠損に大の頭蓋骨片 を移植して成功したてとを記載しているが，研究的意義 の認められるような実験としては，19世紀末に Ollier $(1867)^{2)}$ が行ったのが最初である. その後, 多くの研究 者により, 新鮮骨移植, 保存骨移植, 死骨移植などにつ いて，それぞれ，自家骨移植，同種骨移植，異種骨移植 などの方法により, 移植骨と母骨との関係, 移植骨の運 命, 骨性療合における骨再生原基の由来, 移植骨生着時 の治瘾機転などを特に病理組織学的に検索している。

なかでも移植骨の運命については，Barth $(1893)^{3) ，}$

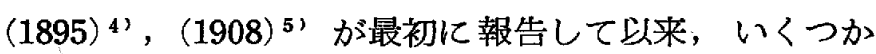
の説がみられる．とれらを大別すると，移植骨がそのま ま超生し，移植骨より新生骨細胞が増殖して生着すると いうもの，移植骨自体には増殖能力はなく，一見死滅し
て吸収されるが, 移植床より造骨細胞が増殖して移植骨 を新生骨組織に置換するもの, さらに移植骨の一部は超 生して造骨機転を与える一方，大部分の移植骨は壊死に 宿り吸収され，同時に移植床よりの細胞增殖により，移 植骨は置換されるという説などがある．乙れらの説は古 来より議論の最も集中するとてろであるが，いまだ明ら かにされていない。

このような骨移植に関する検索は主として，病理組織 学的に行なわれてきたが大内 $(1964)^{6}$ 'は，マイクロラ ジオグラフィと病理組織学的所見 者併用し 検討してい る.また，山本 $(1963)^{7}$ ，秋山 $(1967)^{81}$ などがラジオ アイソトープを用いて 経日的な変化を追求し, Horii $(1974)^{9 \prime}$ は，テトラサイクリンラベリングとマイクロラ シオグラフィを併用して新鮮自家骨移植と他家骨移植の 差異について報告している。しかし，過去に報告された 文献はその比較が脱灭標本による所見であり, 脱灰標本 と非脱灭標本による差を無視したものと思われる。

そこで著者は, 非脱灰標本でテトラサイクリンラベリ ング，マイクロラジオグラフィならびに非脱灰標本を本 
学の島村 $(1971)^{10}$ 'が報告した方法にもとづき染色を行 い, 移植骨の新生, 移植骨の改造, 移植骨の運命につい て検索し，若干の知見を得たので報告する．

\section{実耠動物ならびに実験方法}

\section{1. 実験動物}

実験動物は生後約 1 年の雑種成犬23頭を使用した。動 物は実験前約 1 週間動物飼育舎にて飼育し，健康である ととを確認した後に実験に供した。

\section{2. 実験方法}

実験犬はペントバルビタール注射液 $(0.4 \mathrm{ml} / \mathrm{kg})$ で 静脈麻酔後実験を行った.

まず，両側下額骨下縁部および右側第 4 肋骨部の手術 野を可及的に剃毛し，同部を $0.5 \%$ ヒビテン液で消毒し た. その後, 手術部位を塩酸エピレナミン加 $2 \%$ 塩酸プ ロカインにより局所麻醉を行った。

次いで，右側第 4 肋骨直上の皮膚に 約 $5 \mathrm{~cm}$ の皮虚切 開を加元, 皮下組織, 筋肉, 骨膜を切離し, 肋骨を露出 した. 肋骨を約 $2 \mathrm{~cm}$ の長さに肋骨刃にて切断後, 肋骨 鉜子にて摘出した. 摘出した肋骨はあらかじめ準備して おいた抗生剤加生理的食塩水に浸漬した。そ後, 第 4 肋骨摘出部の骨膜, 筋層, 皮膚の 3 層縫合を行った.

次に，下䫑骨下縁に沿い約 $4 \mathrm{~cm}$ の皮膚切開を加えた 後, 皮下組織, 筋肉, 骨膜を切離し, 乙れら軟組織を骨 膜とともに剶離し，下䫑骨骨体部を露出した後, 第 4 小 日㧘相当部の下颚骨骨体部約 $1.5 \mathrm{~cm}$ ダィヤモンドディ スクおよびマイセルにて切除し，下米槽動静脈および神 経を結禁し切断した。次いで，第 4 小四雨根尖部までマ イセルにて切除して骨創腔を形成した。

その後, 採取した肋骨の上半分に骨䯣が露出するよう に分割し，骨創腔の下方で下疑骨下縁に適合させ， 0.3 $\mathrm{mm}$ の $18 \cdot 8$ 鋼線にて骨縫合し, 骨膜, 筋層, 皮膚の 3 風縫合を行い手術を終った. 術後 2 週間, 抗生剤の筋肉 内注射を行った (写真 1 ).

\section{3. 観察方法}

実験後， $5 ， 10 ， 15 ， 20 ， 30 ， 45 ， 60 ， 90$ 日にペント バルビタール注射液にて薬殺した。薬殺前 3 日間塩酸テ トラサイクリン $15 \mathrm{mg} / \mathrm{kg}$ を静脈注射して, テトラサイ クリンのラベリングを行った.

薬殺後, 実験部位を採取し, $10 \%$ 中性ホルマリンにて 固定後, 右側下影骨の標本は, 通法に従って未脱扊のま ま樹脂包埋を行い, 小坂研究所 $\mathrm{K} \cdot \mathrm{K}$. 製硬組織薄片切断

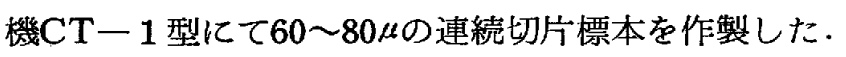

標本は, Nikon 螢光顕微鏡 FS型（BV励起フィルタ
一，東芝製高圧水銀灯 2 SHC-103 LA/B）にて 鏡見し た. 撮影フィルムには Kodak Ektachrome 160 (ASA 160）を使用した。

次いで，標本は，日本ソフテックスK·K·製 Sof texCSM装置を使用し, tube voltage $40 \mathrm{kv}$, tube current $3 \mathrm{~mA}$, distance $40 \mathrm{~mm}$, exposure time 30分の条件下 でマイクロラジオグラフィ撮影を行った．撮影フィルム にはKodak spectroscopic film 649-0 使用した。

"その後, 標本は塩基性フクシン・メチレンブルーの重 染色を行い鏡見した。

一方, 左側下額骨の標本は $5 \%$ 硝酸で脱灰後, 通法に 従ってセロイジン包埋を行い, $15 \mu$ 連続切片を作製し, ヘマトキシリン・エオジンの重染色を行い鏡見した。

\section{実 験 成}

\section{1.テトラサイクリンラベリング所見}

\section{術後 5 日}

母骨上縁断端の一部に網眼状のラベルを, また，母骨 近遠心断端の下靧管相当部に細梁状のラベルを諗める.

移植骨には何ら著変を琶めない。

術後10日

母骨上縁断端における新生骨は細梁状に長くラベルさ れ，骨創腔へ向っている.また，下䫟管相当部の新生骨 はそのゆも広くなり，梁状にラベルされて下顎管中央部 に向っている。

移植骨近遠心断端の骨髅腔において，骨芽細胞と思わ れる点状のラべルを垫めるが, 周囲の骨梁扔よび移植骨 の中央部には何らラベリング像はみられない（写真 2 ). 術後15日

母骨上縁断端からの骨新生はさかんで，さらに骨創腔 へと長く伸展し，その巾も広く，骨梁全体がラベルされ ている.また，下買管相当部からの骨新生は骨創腔へ向 い, その巾も広く, 全体的に強くラベルされている。乙 れは特に遠心側において著明である。

移植骨近遠心断端の骨髄腔では塊状にラベルされ，点 状ラベルは移植骨の中央部へと進んでいる (写真 3 ). また，周用の骨梁では，尖端付近の一部でその表面を一 渞にラベルされた部分も認める。

\section{術後20日}

移植骨上方の骨創腔は周囲母骨より伸展してきた新生 骨のためテトラサイクリンに強くラベルされ，移植骨上 緣へと向っているが, 移植骨との連絡はない，また，下 頻管相当部から骨創腔および移植骨断端上部に伸展して きた新生骨はその巾を增し，強くラベルされているが移 
植骨との連絡はない。

移植骨の近遠心断端付近の骨梁は，その周囲がテトラ サイクリンで一㬝にラベルされ，骨濄腔へと伸展し，一 部は他の骨梁と連絡したラベル像を認める（写真 4 ）. また，骨髄腔内にも網眼状のラベルを認める。しかし， 移植骨断端より母骨へのラベル像はみられない。

術後30日

母骨上縁断端および近遠心断端下䝷管相当部から伸展 したラベル像は移植骨上部を取り囲むようになり，一部 は移植骨断端上部で連絡する (写真 5 ).

移植骨断端では母骨へと伸展する線状のラベル像を認 め，これは母骨から伸展してきたラベル像と連絡してい る (写真 6 ).

移植骨断端付近の骨梁表面にラベルされたものはさら に巾を增している．また，骨髄腔内の新生骨は周囲骨梁 へと伸展し, 新生骨全体を均一にラベルしている. しか し, 中央部付近の骨梁では何らラベルされていないもの が多い。

\section{術後45日}

母骨から伸展してきた新生骨は完全に移植骨と連絡 し, 母骨移植骨断端間は新生骨の巾が広くなり, 骨梁全 体がラベルされた部分や骨梁周囲のみラベルされた部分 などがみられる(写真 7).

移植骨断端付近の骨梁はラベル像の巾が増し，強くラ ベルされている．また，中央部の骨骫有腔では点状にラベ ルされた部分が各所にみられる。しかし，一部では何ら 変化を認めない部分もある.

術後60日

母骨移植骨断端間の骨梁はウが広くなり，骨梁全体が ラベルされた部分は少なく，骨梁周囲に一層の強いラベ ル像を認める (写真 8 ).

移植骨の骨梁もラベル像の巾が広くなり, 各所で骨䯣 腔が狭小となっているが，中央部ではいまだラベルされ ていない骨梁もみられる。

術後90日

新生骨の骨䯣腔は狭小となり，一層のラベルを喼める

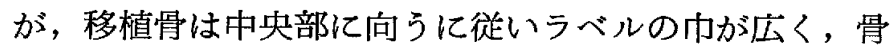
骫有腔も広い。

\section{2. マイクロラジオグラフィ所見}

術後 5 日

母骨上縁断端ではX線吸収の非常に低い網眼状構造の 新生骨を一部認め, 母骨近遠心断端下類管相当部ではX 線吸収の低い細梁状構造の新生骨を認める.

移植骨近遠心断端骨髄腔は胁骨摘出時の骨片がX線不
透過な点状物として認められる（写真 9 ）.

術後10日

母肯上縁断端では小さな骨小腔を形成する細梁状構造 の骨が骨創腔に向って形成され，X線吸収度は母骨から 離れていくに従って低くなっている（写真10）。また， 下顎管相当部の細梁状構造の骨はその巾を増し，下頻管 中心部に向って形成されている．乙の部分のX線吸収度 は骨創腔のものより高い.

移植骨骨梁の一部および移植骨下縁に吸収窝と思われ る不規則, 鋸函状のX線不透過像を喼める（写真11）。

術後15日

母骨上縁断端扔よび下顎管相当部の梁状構造の骨質は 骨創腔抢よび移植骨の方向に形成され，そのX線吸収度 は術後10日よりさらに高くなっている。

移植骨断端付近の骨髄腔にはX線吸収の非常に低い網 眼状構造の像を認める（写真12）。移植骨下縁の 吸収窝 と思われる像はさらに凹凸不整となっている。

\section{術後20日}

母骨上縁断端および下敄管相当部から伸展した新生骨 は移植骨上縁付近沉まで達しているが，いまだ移植骨と の連絡はない。

移植骨断端付近の骨梁辺縁汃らはX線吸収の低い網眼 状構造の骨質を認め，一部の新生骨は骨梁間を連絡する ものもある(写真13)，また，移植骨内の骨梁に吸収窝 を認める (写真14).

\section{術後30日}

母骨断端から形成されてきた新生骨はその巾を増し， X線吸収度も高くなっている，その一部は移植骨の断端 上縁と連絡しているが，そのX線吸収度はあまり高くな く，骨小腔を多数認める(写真15).

移植骨断端から母骨方向入伸展する細梁状構造のX線 吸収の低い骨質を認め，その一部は母骨と連絡している

(写真16). また，断端付近の在来骨梁はその巾を増し ているが，X線吸収はあまり高くない，ての新生骨は骨 梁周辺に均一に形成され，骨髄腔は狭小となっている. しかし，中央部に向うに従い 新生骨の形成は減少する

（写真17）。また, 移植骨下縁の吸収䆟は術後20日の所 見より平坦となっている.

術後45日

母骨と移植骨は近遠心断端部で完全に連絡し，そのX 線吸収も高い骨質となっている（写真18）。しかし，移 植骨上縁では母骨との連絡は一部しかみられない。

移植骨骨梁はその巾を増し，骨髄腔も狭小となってい るが骨小腔を多くみとめ，X線吸収は不均一である。ま 
た，中央部付近では，いまだ骨新生のない部分も認めら れる、移植骨下縁は平坦となり，X線吸収の高い骨質を 恋める。

\section{術後 60 日}

母骨之移植骨は上粶および近遠心断端でほぼ完全に連 䅂を認めるが，在来骨とのX線吸収の差は明瞭で，骨小 腔も多く，配列も不整である（写真19）。また，移植骨 中央部では，いまだ骨新生を認めない骨梁も残存してい る。

術後 90 日

骨質のX線吸収度はほぼ均一となり，骨小腔の配列も 規則的となっている (写真20).

3. 病理組織学的所見

\section{術後 5 日}

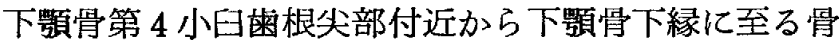
創腔の形成がみられる．その巾径は第 4 小臼歯近遠心巾 径に相当する．また，骨創腔の下部には長方形を呈した 移植肋骨片を誌め，その切断端は下額骨下縁緻密骨およ び下䪽管断端と接合し，その高径は創腔の約 $1 / 2$ 満して いる.

移植骨上部の骨創腔内は血餅，炎症細胞ならびに線維 素網で満されている．移植骨上縁に接する部分では资症 細胞が著明である。

骨創腔上縁断端および近遠心断端骨梁は外傷性変化を 認め，その周囲は一層の肉芽組織がみられ，一部は骨細 胞を含みメチレンブルーに濃染した 新生骨も認められ る。

母骨近遠心断端の下頻管には変性した血管および大き な神経線維束が みられる．その周囲は 炎症細胞が 著明 で，下類管は全体的に線維化が著るしく，骨に接する部 分には骨芽細胞が配列し類骨組織を認めるが，一部では 骨細胞を取り囲んでメチレンブルーに濃染した新生骨も 認められる (写真21，22）。

母骨移植骨断端間は炎症細胞の浸潤が著明で，上，下 方からは幼若な肉芽組織も増殖している（写真23）.

移植骨の近遠心断端および上縁は外傷性変化によりメ チレンブルーに濃染した骨梁を認める，断端付近の骨䯠 腔は骨片, 血餅打よび炎症細胞で淦され, 在来の骨逞細 胞は消失している (写真24)。しかし，内部の骨葡組織 には変化を認めない，また，骨細胞はわずかであるが核 の消失，染色性の低下したものを琶める．移植骨下縁は 粗造となっているが破骨等の変化はみられない.

移植骨下縁に接する軟組織内は一部炎症細胞を諗める が，全体的には豊富な新生血管を含んだ幼若肉芽組織が
みられ，母骨近遠心下縁からは線維芽細胞の著るしい浸 潤が䍿められる。

術後10日

骨創腔内の線維素綿は密となるが, 血餅, 炎症細胞は 残存している.

骨創腔上縁断端および近遠心断端に浔められる肉芽組 織は骨創腔中央および移植骨上縁部に向って増殖してい る．骨創腔上縁断端および近遠心断端では骨細胞を取り 囲んだメチレンブルーに濃染する新生骨を各所に恋め， その周囲には骨芽細胞を豊富に認める。

母骨下顎管の神経線維束は変性が著明で，その周囲に は一部炎症細胞を認める、下筼管周辺部では新生骨を各 所に認め，それは骨創腔および移植骨断端へ向って増殖 している。

母骨移植骨断端間では一部炎症細胞 が残存している が，その上，下方上り幼若肉芽組織の増殖が盛んで，下 顎管断端では骨芽細胞も認められる(写真25).

移植骨断端付近の骨髄腔では下額管と接する部分で肉 牙組織の進入がみられ，一部線維化し，骨芽紐胞の出現 も認めるが，骨梁辺縁への配列はみられない（写真26）。 さらに中央側骨髄腔では血餅，炎症細胞も残存し，在来 骨娟道組織の融解などがみられるが，中央部では何ら変化 を認めない，移植骨断端上部では一部で破骨細胞の出現 も䜑められる（写真27）。骨細胞は術後 5 日に較べさら に核の融解，消失，染色性の低下などが著明である（写 真28)。また，骨梁の一部で辺縁部が融解している部分 も認められる．移植骨下縁の粗造な所見は術後 5 日より さらに著明であるが，破骨細胞の出現は認められない，

移植骨下緣に接する肉芽組織はさらに増殖し，その巾 を増すとともに，新生毛紐血管を豊富に認める。

術後15日

骨創腔内は わずかに血餅，炎症細胞の残存を誌める が，ほぼ肉芽組織で満されている。

骨創腔上縁断端および近遠心断端からの新生骨は血管 を含み梁状形成をして中央部に向って増殖している，移 植骨上縁に接する部分では肉芽組織を一㬝認め，一部で は移植骨骨䯠腔へ進入し，骨芽細胞を認めるが，骨梁周 囲への配列は認めない。

母骨近遠心断端の下買管では変性した神経線維束は融 解し，その周囲は血管を取り囲んだ新生骨梁で満されて いる、ここより新生した骨梁は骨創腔抢よび移植骨断端 部へと進むが，いまだ移植骨とは連絡なく，一首の肉芽 組織によって境いされている。

母骨移植骨断端間は肉芽組織で満され，下䩄管に接す 
る部分では 線維化が進み密となっている，また，移植 骨断端骨髄腔は線維芽細胞が豊富に進入している（写真 29) .

移植骨内の肉芽組織はさらに中央部に向って増殖し， 新生血管も豊富に諗められる。しかし，それよりさらに 中央部ではいまだ血餅の残存を垫め，骨䯋細胞は融解消 失しているが，一部では在来の骨咀組織の形態を保って いる，断端付近の骨髄腔には骨牙細胞が豊富に虫めら れ，その周囲には線維牙細胞が多くみられるが，一部の 骨芽細胞は骨梁辺縁に配列している（写真30）。 また， 残存血餅は器質化し, 一部メチレンブルーに淡染し, そ の周辺に骨芽細胞声認める (写真 $31 ， 32$ ). メチレンブ ルーに淡染した新生骨は在来骨梁とは関係なく増殖し, 在来骨梁辺縁汇配列した骨芽細胞からの石灰化は認めら れない，また，その付近には破骨細胞の出現も㸾められ る.また, 移植骨の上, 下部では破骨細胞の出現が著明 で，骨吸収像を呈する部分も㦘められる，在来骨梁の骨 細胞は術後10日に較べ核の消失, 融解したものの数はわ ずかに増加している。

移植骨下縁に接する軟組織内は大きな動脈性血管が豊 富で，その下方においては不規則な走行を呈する結合織 を珰める。

\section{術後20日}

骨創腔の新生骨はさらに骨梁の巾を增し，骨䯣腔には 血管と柾な線維組織を入れている。しかし，いまだ血餅 の残存も認める、移植骨上縁に接する部分の肉芽組織は 線維化がみられ，移植骨骨髄腔入進入している。

母骨近遠心断端の下箩管では新生骨梁が巾を増し，さ らに増殖が盛んであるが，いまだ移植骨との連絡はな く，一層の肉芽組織で境いされている.

母骨移植骨断端間の肉芽組織は線維化がみられるが， 配列は疎で, 線維芽細胞が豊富にみられ, 移植骨へと進 入している。

移植骨骨髄腔はほぼ肉芽組織で満され，血管を豊富に 認める、また，中央部では，いまだ在来の骨䯣組織がみ られるが，骨髄細胞はやや融解している (写真33)。断 端付近にみられた新生骨はさらに中央部へと進み, 在来 骨梁周囲からの新生骨梁も各所で認められる(写真 34 , 35）。また，骨梁辺縁の破骨細胞も各所で認められる (写真 36,37 ). 在来骨梁の骨細胞の融解, 消失は術後 15日と変化ないが, 形成された新生骨の骨細胞は豊富に みられる。移植骨下縁では骨吸収が著明であるが，一部 骨新生も認められる.

移植骨下縁に接する肉芽組織は移植骨骨䯣腔へ向って
進入している．また，結合織の走行はやや規則的とな る.

\section{術後 30 日}

骨創腔の新生骨梁はさらに増殖し，移植骨上部之連絡 する部分を一部認める (写真38)。しかし，移植骨に接 する大部分はいまだ肉芽組織で被われている。

母骨近遠心断端の下額管にみられた新生骨は一部移植 骨断端と連絡する部分を認める。しかし，移植骨に接す る母骨断端の緻密骨においては著変を認めない。

移植骨骨逞腔はほぼ肉芽組織で満され，断端は線維化 が密で中央部へ向うに従って疎となっている（写真39）。 在来骨梁に配列した骨芽細胞も新生骨を形成し，乙れら は骨髄腔へと向って増殖し，移植骨上部付近では骨創腔 や断端へ向うものもあり，一部は母骨からの新生骨と連 絡している。また，移植骨下部では上部よりさらに骨新 生が盛んであるが, 移植骨下縁付近は骨の吸収, 添加が 盛んである。

移植骨下部の新生骨に接する肉芽組織の巾は減少し, 疎性結合織一と移行している。

術後45日

骨創腔の新生骨はさらに币を增し，骨髄腔は豊富な血 管および線維組織を含んでいる。移植骨上縁に接する部 分はいまだ肉芽組織で境いされた部分も認められる。

母骨近遠心断端からの新生骨も著明で，母骨移植骨断 端間には石灰化を起したメチレンブルーに淡染した組織 で満され，各所で移植骨と連絡している（写真40）。

移植骨の近遠心断端では，母骨と連絡が終り，境界の 不明瞭な部分を一部認める。しかし，造骨した骨細胞は 数が多く，配列が不規則である．また，新生骨を形成す る骨檤腔は線維組織が密であるが, 中央部に向うに従っ て疎となっている，また，中央付近の在来骨梁周囲には 骨芽細胞が多数配列している (写真41). 移植骨上, 下 部ではいまだ破骨細胞を認めるが, 移植骨下部では造骨 も著明である (写真42).

移植骨下縁に接する部分では一層の疎性結合織を認め る.

\section{術後60日}

骨創腔はほぼ新生骨で満され, 骨の改造が盛んで, 骨 のウが広く血管を含んだ小さな骨髄が各所にみられる。

母骨移植骨断端間を満した新生骨は巾を増し周囲に骨 芽細胞が配列し，骨髄は血管，肉芽組織で満されてい る.また, 在来骨との染色性の違いは不明瞭であるが, 骨細胞は多く，配列は不整である(写真43，44）。乙の新 生骨は移植骨へと続き，移植骨の中央部に向っている. 
移植骨中央部では骨䯣の線維組織が密となり, 在来骨 梁周团には骨芽細胞が配列している。しかし，一部の骨 梁はまったく変化を認めない部分もある．また，移植骨 上部は骨創腔からの新生骨之連絡し， 中を増している. 移植骨下部では造骨とともに，いまだ破骨細胞を認め る.

術後90日

骨創腔と思われる部分および母骨断端の下㖽管相当部 では脂肪喣を呈し，骨細胞の配列が規則的となってい る。

母骨移植骨断端間および移植骨断端付近では骨の改造 が盛んである。

移植骨中央部では一部いまだ在来骨梁の残存が認めら れ，その周用は密な線維組織で満されている（写真45）。 断端付近の骨は改造が盛んで, 骨細胞も数が減少し, 配 列が規則的となっている (写真46).

\section{総括ならびに考察}

著者は成犬を用い，下顎骨骨体部を部分切除後，新鮮 自家肋骨を移植し，移植骨抢よび母骨の変化について， テトラサイクリンラベリング， マイクロラジオグラフ 1, 非脱灭標本の塧基性フクシン・メチレンブルー染色 および脱灰標本のへマトキシリン・エオジン染色による 病理組織学的所見について検索し，前記のごとき成績を 得た。

これらの成績を総括し, 移植骨における骨新生, 移植 骨の改造，移植骨の運命について検討を加えた。

術後の反応性炎症は, 術後 5 日では移植骨上縁骨創腔 および母骨と移植骨の近遠心断端間が血餅，線維素網， 炎症細胞で満されている. 術後10日の移植骨上縁骨創腔 は血餅，炎症細胞は残存するが，線維素網は密となり， 周囲より増殖してきた幼若肉芽組織により取り囲まれ小 さくなってきている．また，母骨と移植骨近遠心断端間 は血餅の残存を認めるが，上，下部より幼若肉芽組織の 増殖がさかんである．術後15日においても骨創腔ではわ ずかではあるが血餅を認める。しかし，母骨と移植骨近 遠心断端間の反応性咨症亚消退している．骨創腔の反応 性炎症の消退は長いものでは術後30日までみられる。

骨創腔における反応性炎症の消退遅延は骨創腔を大き くしたためである. 即ち, 下頡骨連続離断後の移植骨固 定不良による治療経過の不均一をなくすよう, 移植骨固 定の一手段として匊槽部を残したために出来たものであ ろ.しかしながら，母骨移植骨断端間の所見は，大内 $(1964)^{6)}$ などの 報告したラット下顎部における 架橋的
骨移植例の経日的見所と大差はない。

母骨断端部に抢ける骨新生の所見は，術後 5 日に母骨 上縁断端で一部類骨組織の形成がみられる。また，近遠 心断端下額管は神経束の周囲に線維組織が形成され，下 顎管周囲骨には骨芽細胞が配列し，メチレンブルーに濃 染した新生骨が梁状に形成されている。この部分のテト ラサイクリンラベリング所見では網眼状のラベルが認め られ，マイクロラジオグラフィでは石灰化の搦い細梁状 構造を認める。

術後10日には，母骨上縁断端でメチレンブルーに濃染 する細梁状の新生骨が骨創腔へ向って形成され，下顎管 では管中心部に向って伸展している・テトラサイクリン ラベリング所見では細梁状で全体的にラベルされた像を 呈し，マイクロラジオグラフィでは細梁状構造のX線吸 収の低い像としてみられる。母骨上縁断端の新生骨は下 顎管のそれより石灰化が弱いが，梁状の長さがわずかに 長いようである。

術後15日には母骨上縁断端からの骨新生は急激に形成 され，梁状で大小不規則な骨髄腔を作りながら骨創腔の 中央部へと進行している，下顎管では変性した神経線維 束付近まで新生骨が形成され，骨創腔および移植骨断端 へと進んでいる．また，母骨断端の緻密骨においては骨 の新生はまったくみられない，テトラサイクリンラベリ ング所見では梁状に細長くラベルされ，マイクロラジオ グラフィ所見では梁状のX線吸収のやや高くなった像を 認めるが，骨創腔に向うに従ってX線吸収の低い網眼状 構造を呈している。

術後20日には，母骨上縁抢よび近遠心断端から伸展し てきた新生骨は移植骨と一層の肉芽組織で境いされるほ どに形成されている．母骨近遠心断端下縁部の緻密骨は 一部吸収を認めるが，骨の新生はまったくみられない。

術後30日には，母骨から伸展してきた新生骨が移植骨 断端上部および 移植骨上縁部において一部連絡を認め る.テトラサイクリンラベリング所見では移植骨辺縁に 一風のラベルを認め，連絡した個所は新生骨が全体的に ラベルされている．マイクロラジオグラフィではX線吸 収のやや高い梁状構造として認められるが，移植骨のX 線吸収は非常に高い。

母骨からの骨新生は海綿骨周囲と下類管からの形成が 著名である．下靧管の線維化や新生骨は術後 5 日にすで に著明にみられる.乙れは下笡管に大動静脈が走行し， その周囲には疎性結合織があるため，乙の疎性結合織の 残存したものが線維化を促進させると考える．また， Deleu and Trueta (1965) ${ }^{11}$ が骨新生に血管の新生が 
重要な役割を演じると述べているように，ての管に大血 管があることにより新生骨の早期形成が起るすのと思わ れるが，てれに関する報告はいまだみられない。さらに 同部が特異的に作用するのであれば，移植骨を母骨に結 合させる時，ての点に着眼すれば骨性療合促進をきたす のではないかと思われる. この点に関しては今後, 詳細 に検索する必要がある。

また，移植時における 海綿骨と緻密骨の差に関する 報告はBush (1948)12)，Wilson (1951)13)，Odell

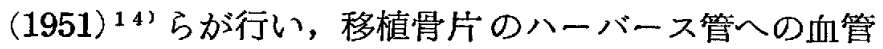
再生が速い方が治療も速いという事実から, 多孔性の海 綿骨の方が緻密骨より治療が速い之述べている。また，

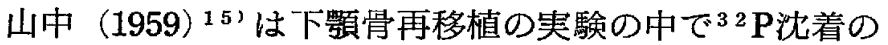
観察により海綿骨より緻密骨の方がはるかに低いが，術 後 3 週より移植床と同率となると述べている。

著者の実験においても，早期の骨新生は海綿骨からで あり，緻密骨からの新生は術後 30 日以後であることから して，母骨であっても明らかに海綿骨の方が早期に新生 骨を形成することがわかる。

次に移植骨についてみると, 術後 5 日には移植骨の近 遠心断端および上縁は外傷性変化によりメチレンブルー に濃染した骨梁を認める。移植骨近遠心断端部の骨䯣腔 は骨片, 血餅, 炎症細胞で満され, 在来の骨髄細胞は消 失している.しかし, 内部の骨髄組織には変化はみられ ない．また，骨細胞は一部膨化した核や融解したものを 認める. 移植骨下縁は粗造となっているが破骨等の変化 はみられない。

術後10日には移植骨断端部骨髄腔は血餅が器質化し, 母骨側から幼若肉芽組織の進入を認める．特に下靧管に 接する骨躈腔には骨芽細胞を認める。また，移植骨断端 上縁では破骨細胞の出現をみとめる．テトラサイクリン ラベリング所見では骨芽細胞活性による点状のラベルを 一部に認める.しかし，マイクロラジオグラフィにおい ては著変はみられない，また，骨細胞は核の融解，消失 したものの数が増加している。

術後15日には移植骨断端部骨髄腔の器質化した血餅の 周囲に骨芽細胞がみられ，器質化した部分の一部はメチ レンブルーに淡染した骨椂物質を認める．また，在来骨 梁は破骨細胞による骨の吸収と同時に，骨芽細胞も認め られる．それより中央部にある骨䯣腔は炎症細胞の浸潤 により骨髄細胞の消失，幼若肉芽組織の増殖を認める。 テトラサイクリンラベリングでは骨娟有腔で塊状のラベル を認める。また，マイクロラジオグラフィではX線吸収 の非常に低い像としてみられる．また，骨細胞の消失は
さらに著明となる。

術後20日には骨牙細胞が 多数，在来骨梁周辺に 配列 し，新生骨の形成がさかんである。その付近の骨梁には 破骨細胞や骨の吸収像がみられる、移植骨中央部では骨 髄細胞は一部を残しほぼ因芽組織に置換している。テト ラサイクリンラベリングでは在来骨梁周囲に著明なラベ ルを認めるが母骨方向への伸展はない，また，マイクロ ラジオグラフィではX線吸収のあまり高くない石灰化像 が在来骨梁や骨髄腔にみられる．また，骨細胞は術後 15 日に較へ数の減少はなく，周囲新生骨の骨細胞がさかん に増加している。

術後30日には移植骨骨梁全体におろいて，骨の新生がさ かんで，移植骨断端上部では母骨から形成された新生骨 と連絡している．在来骨梁は消失することなく，その周 囲に骨新生がみられ，骨髄腔は狭小となり付近の新生骨 と連絡するようになる。また，移植骨断端の一部から母 骨に向って新生骨の形成もみられる．テトラサイクリン ラベルリングによると，術後20日よりもラベルの巾が広 くなり，梁状を形成している。しかし，中央部へ向うに 從ってラベルの巾は瘗くなり，石灰化の遅いことがわか る・また，母骨と連絡した部分では網眼状のラベルを琹 める. さらに，移植骨断端では母骨に向う線状のラベル がみられる、マイクロラジオグラフィでは母骨と移植骨 の連絡部では，X線吸収がやや高くなっているが，移植 骨断端から伸びた新生骨はX線吸収が低い。

術後45日には母骨と移植骨の連絡する部分はさらに币 を增し，一部では下縁においても連絡する 部分を認め る.また，移植骨中央部ではいまだ在来骨梁が残存して いる。

術後60日には母骨および移植骨の断端部で骨の改造が 盛んであるが，骨細胞は数が多く配列は不規則である。 また，移植骨中央部ではいまだ骨新生のみられない在来 骨梁もみられる。

術後90日では移植骨はさらに骨改造が中央部へと進 み，断端付近の骨髄では脂肪髄もみられる。また，骨細 胞の配列も規則的となっている。しかし，中央部ではい まだ在来骨梁の残存もみられる。

移植骨の骨新生に関する骨芽細胞の 発生由来につい て, Ollier $(1867)^{2)}$ は骨膜にその起源を求めており， Axhausen (1950) ${ }^{16)}$ は移植骨骨膜を剝離しても深部に 間葉性細胞が残っているので骨の形成が可能であると述 べている.

一方, 河村 $(1954)^{17}$ ，杉山 $(1952)^{18}$ ' 引は海綿骨移 植で骨盏細胞および血管壁内皮細胞によって直ちに骨に 
添加増殖がなされていることから推して，骨髄組織を重 要視し, Burwell $(1964)^{19)}$, Richter $(1968)^{20)}$ は移 植骨の骨髄組織に造骨能のあるてとを指摘している。ま た，小野 $(1973)^{21}$ 'は骨葡組織除去自家肋骨移植により 骨髄組織の重要性を強調している。

これに対し, Leriche and Policard (1926) ${ }^{22}$, Bier (1913) $\left.{ }^{23}\right)$ らは移植骨周囲の結合組織汃ら骨芽細胞 への分化が起って, 新生骨が形成されるに至ると述べて いる。

著者の所見では, 術後15日に血餅が器質化した骨蹎腔 に血管が豊富にみられ，器質化したものはメチレンブル 一に淡染し，その付近に骨芽細胞を豊富に怣め, 一部骨 細胞へ変化している，さらに骨髄組織の融解と同時に肉 牙組織に置換し，漸次中央部へと進行している。このよ うなととからすれば骨髄組織に造骨能があるととも考え られる.乙のことに関しては, 今後詳細に追求する必要 があると思われる。

しかし，肉芽組織は移植骨周囲から増殖してきた線維 芽細胞により線維化が起っている。乙の部分では周囲骨 梁に無関係に骨来細胞が出現している，さらに，一部で は骨芽細胞の骨髄腔進入の所見もみられているととから すれば，骨芽細胞の発生は，移植骨周四結合組織による ものと断定できる。

さらに，乙の結合組織から骨新生を誘導する物質とし $\tau$ ，Levander (1938) 24) は組織が特殊な 方向に 分化 する傾向を可能偟する要素を induction と命名し， Induction theory なる概念を導入している. その後, Lacroix $(1947)^{25)}$ は Osteogen と呼ぶ物質により説 明し，中村 $(1956)^{26}$ は盈片移植により，その部の結合 組織注ある変化が起り, 骨新生を促す所見を認め, ての 物貿に Osteotaxin と名付けたいと述べている。しか し，いまだ解明されるに至らず今後の研究がまたれる。 移植冎の改造については, Barth (1895) ${ }^{4}$ ', Phemister $(1914)^{272 ， 山 中(1959)^{28}}$ はハーバース管などの搪大に 伴い, 新生血管が移植骨内に侵入し, 在来骨質の吸収と 新生兴の添加に上って次第に置換されるという潜行性の 置換を，Axhausen (1909) ${ }^{29}$ は吸収と添加による置換 を主張しているが，河村 $(1954)^{17}{ }^{17}$ は主として，海綿骨 資では潜行性の置換を，また維密骨質では吸収と添加に よる置換の形成をとると述べている.

著者の所見では，移植骨骨梁周辺に新生血管は認める が，移植骨內への侵入は明確でなく，また骨の吸収，添 加は骨賈に関係なくみられていることからして, Lexer (1924) " $)^{\prime}$ う移植骨の治療条件によっては，てれらの
両方の置換過程がみられるのではないかと考える.

また，移植骨と母骨との骨性痖合の際の軟骨の出現に つては, 大内 $(1963)^{6)}$, 山本 $(1963)^{n}$ らはラット下 顎骨に新鮮自家肋骨の架橋的骨移植を行い軟骨の出現を 報告し，乙れは肋骨のもつ生物学的特殊性によるもので あると述べているが，青柳 $(1966)^{30}$ はラット下顎骨に 新鮮自家腸骨，脛骨および腓骨の架橋的骨移植を行い， 軟骨の形成が起ったのは腓骨のみであることからして， 移植骨の特殊性よりはむしろ，その大きさならびに機械 的刺激によるものであろうと述べている.

著者の実験においては，軟骨の出現はまったくみられ ず，機械的刺激も少ないてとからして，河村 $(1942)^{31}{ }^{3}$ ， $(1950)^{32)}$ ，青柳 $(1966)^{30)}$ が指摘したように，移植骨 の特殊性によるものでなく，機械的刺激によるものと思 われる。

移植骨の運命については, Barth $(1893)^{3)},(1895)^{4)}$, $(1908)^{5)}$ が移植骨のすべての要素は死㓕し，その母床か ら生じる新生骨によって置換されるものであると報告し て以来, 多くの研究者により，いろいろの説が述べられ た. Reynold and Oliver $(1950)^{33)}$, 中島 $(1955)^{34)}$, 河村 (1958) ${ }^{35}$ ) 弓は新鮮自家骨と保有骨との移植経過を 比較して，いずれの移植骨にも造骨能のないととを認め ている. また, 大内 $(1963)^{6)}$, 山本 $(1963)^{71}$, 松本 $(1966)^{36}{ }^{3}$, 青柳 $(1966)^{30}$ ), 秋山 $(1967)^{8)}$ らも移植 骨の骨細胞は壊死に陌って死㙎するものであるとして，

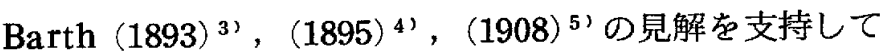
いる。

これに対し，Axhausen (1909) 29)，Phemister $(1914)^{271}$, Albee (1923) ${ }^{37)}$, Campbell (1953) ${ }^{387}$, 河村 $(1954)^{17)}$ などは自家骨移植においては, 移植骨 骨細胞の一部は生存し，骨新生ならびに母骨との骨性痖 合などに関係すると述べている，しかしながら，ての見 解は移植条件により異っていて, 河村 $(1954)^{17}$ は移植 骨の海綿骨質のみ，骨細胞が生き残って造骨能があると し，山口 $(1959)^{39}{ }^{\prime}$ は最終的に大部分の移植骨骨細胞は 死滅するが，ある一定期間だけ一部の骨細胞は生き残っ て，骨新生に関係すると述べている.

著者の所見では, 移植骨の骨細胞は完全に死隇するこ となく, 術後15日までは骨細胞の消失が多くなるが, 術 後20日には骨周囲に骨新生が起り，新生骨と接する部の 骨細胞は正常な所見を呈している。また，テトラサイ クリンラベリング, マイクロラジオグラフィいずれの所 見に扔いても在来の骨梁は明らかに残っているてと， さらにその周囲に新生骨が証明されることからして， 
Axhausen (1909)291などが述べているように，一部の 骨細胞は生き残って，骨新生や母骨との骨性癒合に関俰 していると考える。

\section{結論}

著者は雑種成犬（生後約 1 年）23頭を使用し，下顠骨 部分切除部に新鮮自家肋骨を移植し，移植骨および母骨 の変化をテトラサイクリンラベリング，マイクロラジオ グラフィによる観察を行い，さらに非脱灰染色標本およ び脱灰染色標本を病理組織学的に検索し，次の結論を得 た。

1. テトラサイクリンラベリングにて，母骨では特に 下類管において術後 5 日から，移植骨では術後15日から 新生骨のラベルがみられた。

術後30日には移植骨断端上部で母骨か5の新生骨によ り移植骨と連絡するラベルを認めたままた，一部移植骨 断端から母骨に向って形成される新生骨のラベルを認め た。

術後45日〜 60日では母骨移植骨断端間の新生骨は愲梁 が全体的にラベルされているが, 術後90日には骨咀腔周 辺に一層のラベルを想めるのみとなる．

2. マイクロラジオグラフィにて，母骨では術後 5 日 に，移植骨では術後15日にX線吸収の低い網眼状構造の 石灰化像を認めた：

術後30日には移植骨断端上部で母骨からの新生骨によ り，移植骨と連絡する梁状のX線吸収像を垫めた。ま た, 移植骨断端から母骨に向う新生骨はX線吸収が低い 石灭化像を認めた。

術後45日〜 60日の母骨移植骨間の新生骨の石灰化は低 く, 在来骨とのX線吸収には著明な差がみられるが, 術 後90日にはX線吸収はほぼ同程度となった。

3. 非脱灰標本および脱灰標本において，母骨近遠心 断端下顽管では術後 5 日に線維化が著るしく，他部より 骨新生もさかんである。

移植骨骨葡腔は断端部汃ら中央部一向って, 漸次肉芽 組織へと変化し, 術後30日にはほぼ肉芽組織への置換を 終了した.

術後10日に移植骨断端骨髄腔に骨芽細胞を認め, 術後 15日には石灰化像を認めた。

術後20日には移植骨骨梁の骨新生がみられ，漸次中央 部へ形成された。

術後30日には母骨と骨性瘾合を起し, 術後45日にはは ぼ中央部まで新生骨が形成されたが，在来骨梁の残存も みられた。
術後60日には移植骨断端部では骨改造がさかんで, 術 後90日には脂肪能化し，骨細胞の配列も規則的である。 しかし，移植骨中央部ではいまだ在来骨梁もわずかであ るが認められた。

4. 本実験において，移植骨骨細胞は完全に死减する ことなく，骨新生ならびに母骨との骨性療合に関係して いると思われる。

稿を終るに臨み, 終始, 御想篤なる御指導・御校閲を 賜った恩師九州䨑科大学第一口腔外科学教室山田長敬教 授ならびに九州画科大学口腔病理学教室上野正康教授に 深甚の謝意を捧げます．また種々の御助言を賜った九州 霜科大学口腔細菌学教室内山長司教授ならびに九州歯科 大学口腔組織学教室藤英俊講師に衷心よりの感謝の意を 表するとともに，本研究に御協力いただいた教室員各位 に深く感謝いたします。

\section{引用 文 献}

1. Lexer, E. : 20 Jahre Transplantations Forschung in der Chirurgie, Arch. f Klin. Chir. 138: 251-302, 1925 .

2. Ollier, J. L. : Traité expérimental et clinical de la régénération des os et de la production artificielle du tissu osseux, Masson et Fils, Paris, 1867. cit. by 17.

3. Barth, A. : Ueber histologische Befunde nach Knochenimplantation, Arch. f Klin. Chir . 46: 409-417, 1893.

4. Barth, A. : Histologische Uutersuchungen über Knochenimplantation, Beit. Path . Anat. u Allgem. Path. $17: 65-142,1895$.

5. Barth, A. : Ueber Osteoplastik, Arch. f Klin. Chir. $86: 859-872,1908$.

6. 大内一雄：ラットの下預部における自家骨移植の研 究, 歯科月報 $37: 340-361.1964$.

7. 山本郁也： $\mathbf{P}^{32}$ の追跡実験による下顎骨への自家骨 移植の研究，歯科月報 $37: 362-380,1963$.

8. 秋山 清 : ラット下䫟部の架橋的骨移植に関する研 究, 日大菌学 $41: 621-638,1967$.

9. Horii, H. : Experimental studies on the reorganization of bone grafts by the use of tetracycline labelling, Bull. Stom . Kyoto.Univ. $14: 1-26,1974$.

10. 島村昭辰・藤英俊・他：硬物質薄切装置による歯 
とその周四組織の非脱灰的切片調整法, 歯基礎 医会誌 $13: 62-69,1971$.

11. Deleu, J. and Trueta, J. : Vascularisation of bone grafts in the anterior chamber of the eye, J. Bone Joint Surg . 47-B : 319-329, 1965.

12. Bush, L. F. : The bone bank, J. Amer. Med. Ass. $137: 588-594,1948$. cit. by 15.

13. Wilson, P.D. : Experience with the use of refrigerated homogenous bone, J. Bone Joint Surg. 33-B : 301-315, 1951.

14. Odell, R.T. : Effect on bone grafts of radio-active isotopes of phosphorus, $\mathrm{J}$. Bone Joint Surg. 33-A : 324-332, 1951. cit. by 15 .

15. 山中朝善：下顎骨再移植に関する実験的研究，大 阪大菌誌 $4: 601-620,1959$.

16. Axhausen, W.: The osteogenic phases of regeneration of bone, J. Bone Joint Surg . 38-A : 593-600, 1956.

17. 河村謙二：骨移植, 医学書院, 東京, 1954, 6086.

18. 杉山フカシ：龸膜之骨䯙の骨新生並に骨再生に関 する研究，京都府医大誌 $51 ： 24-47 ， 1952$.

19. Burwell, R. G. : Studies in the transplantation of bone, J. Booe Joint Surg. 46-B : 110-140, 1964 .

20. Richter, H.E. : Stimulation of osteogenesis in the dog mandible by autogenous bone marrow transplants, Oral Surg. $26: 396-$ 405,1968 .

21. 小野正道：ラット下頡部における骨鹃道組織除去自 家肋骨の架橋的骨移植に関する研究，日大隶学 $47: 555-567,1973$.

22. Leriche, R. and Policard, A.: Some fundamental principles in the pathology of bone, Surg. Gynecol . Obstet. $43: 308$ $-309,1926$.

23. Bier, A. : Beobachtungen über Knochenregeneration, Arch. f Klin. Chir. 100: 91-113, 1913 .

24. Levander, G.: A Study of bone regeneration, Surg. Gynecol. Obstet. 67:705-714, 1938.
25. Lacroix, P. : Organizer and the growth of bone, J. Bone Joint Surg. 29:292-296, 1947. cit. by 26 .

26. 中村平蔵：㴿部骨移植について, 日曰外誌 $2: 3$ $-10,1956$.

27. Phemister, D.B. : The fate of transplanted bone and regenerative power of its various constituents, Surg. Gynecol. Obstet. $19: 303-333,1914$.

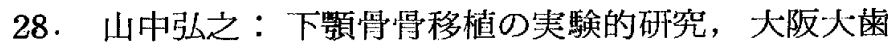
䓽 $4: 871-908,1959$.

29. Axhausen, G. : Die histologischen und klinischen Gesetze der freien Osteoplastik auf Grund von Thierversuchen, Arch. f Klin. Chir. 88:23-145, 1909.

30. 青柳裙吉：ラット下顎骨に抢ける 新鮮自家腸省, 脛骨および腓骨の架橋的骨移植について，日大 雨学 $40: 508-530,1966$.

31. 河村謙二：保存骨移植, 日外会誌 $43: 892-893$, 1942.

32. 河村謙二：「骨の銀行」並びに 同種保存骨移植に 於ける移植片の組織特異性の脱却に就て，臨外 $5: 525-528,1950$.

33. Reynolds, F.C. and Oliver, D.R. : Experimental evaluation of homogenous bone grafts, J. Bone Joint Surg. 32-A : 283297,1950 .

34. 中島政彦：䝪蔵骨移植の実験的研究, 口病誌 $22: 255-267,1955$.

35. 河村正昭：顎部骨移植の実験的研究, 口病誌 $26: 2057-2078,1958$.

36. 松本博雄：ラット下頻骨の 自家肋骨移植における 移植部および血清のフォスファターゼに関する 組織化学的ならびに生化学的研究, 日大奥学 $40: 371-390,1966$.

37. Albee, F.H. : Fundamentals in bone transplantation, J. Amer. Med. Ass. 81 : 1429-1432, 1923.

38. Campbell, C. J. : Experimental study of the fate of bone grafts, J. Bone Joint Surg. 35-A : 332-346, 1953.

39. 山口勝：家兔に扔ける骨移植の実験的研究．第 1 編 諸種移植骨材料による下顎骨にお引る移植 奏験，口科誌 $8: 593-614 ， 1959$. 


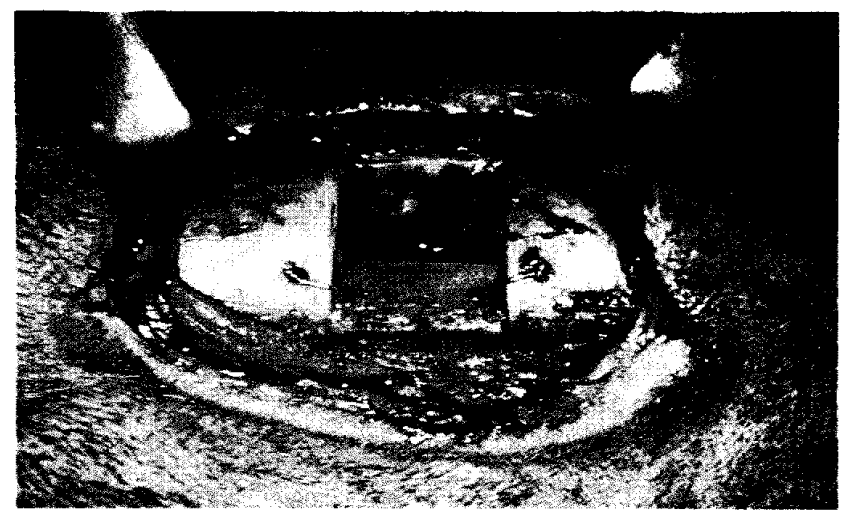

If I? 1

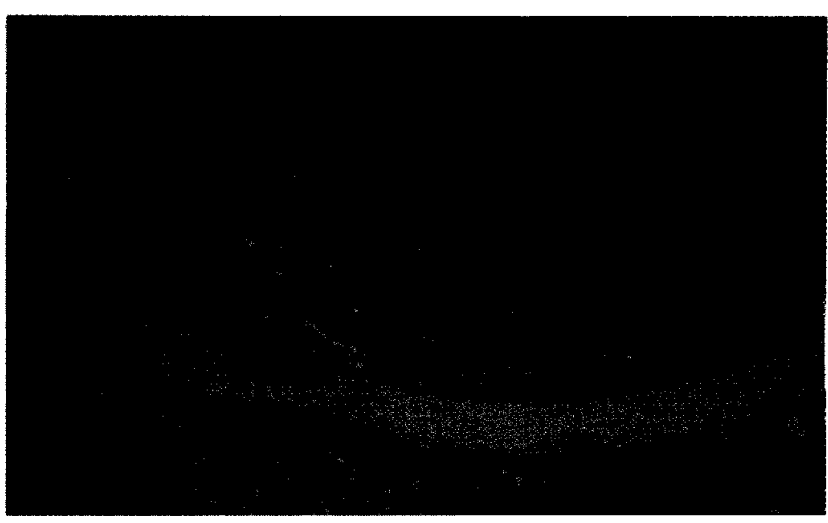

'

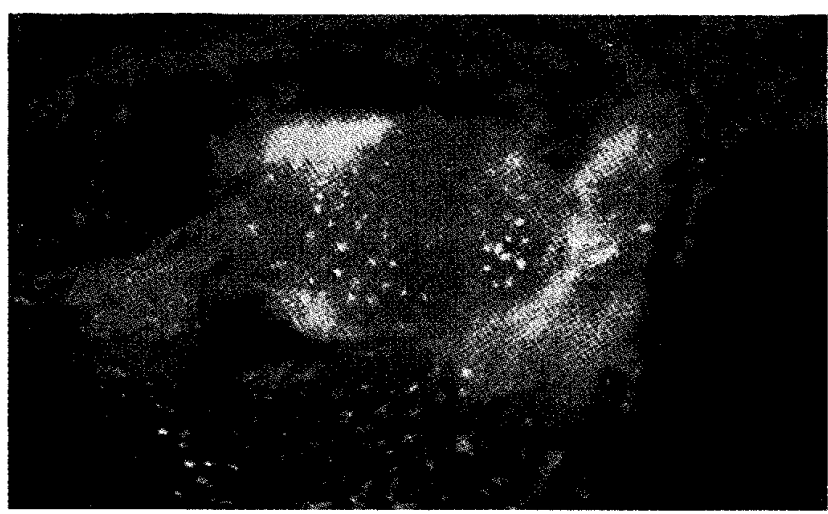

$\because j+1$

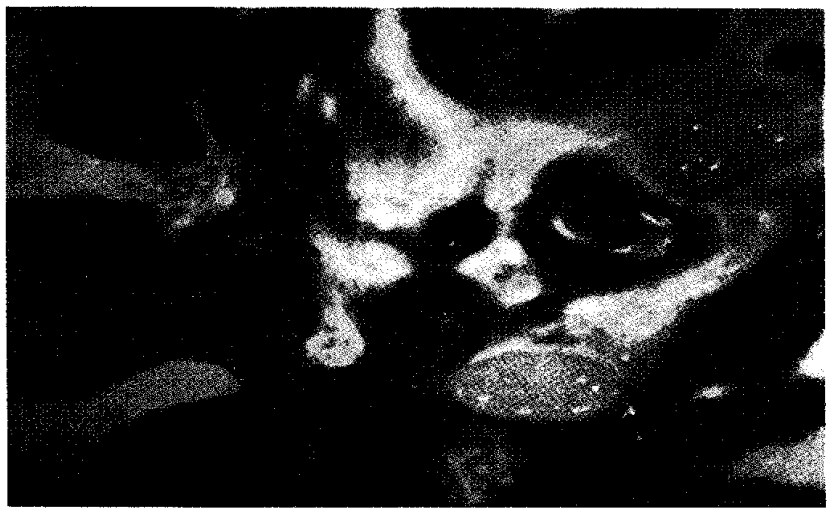

$1: 144$

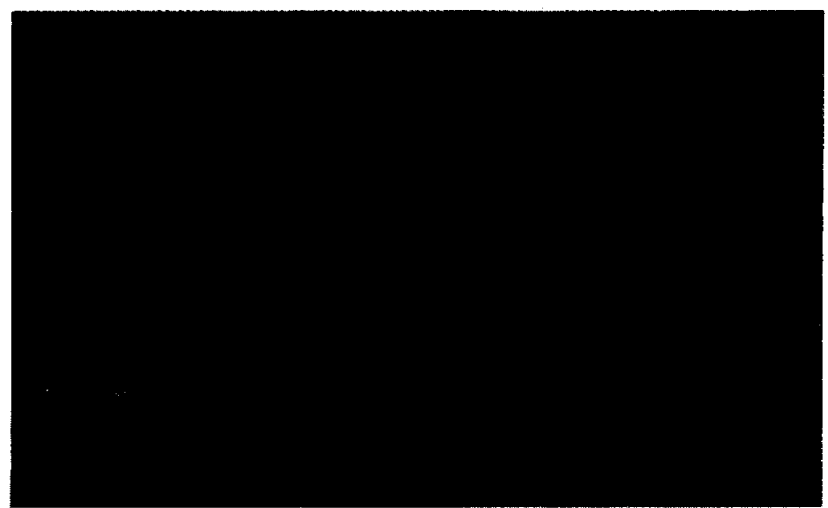

3 j. 息 5

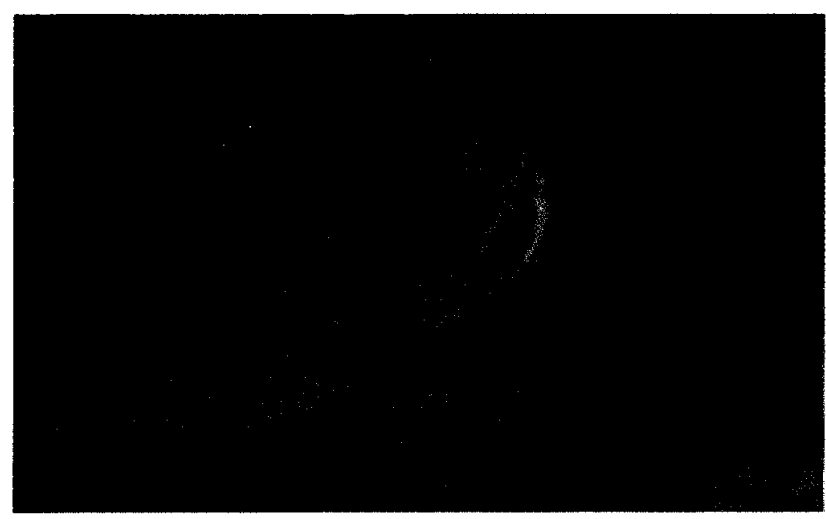

?

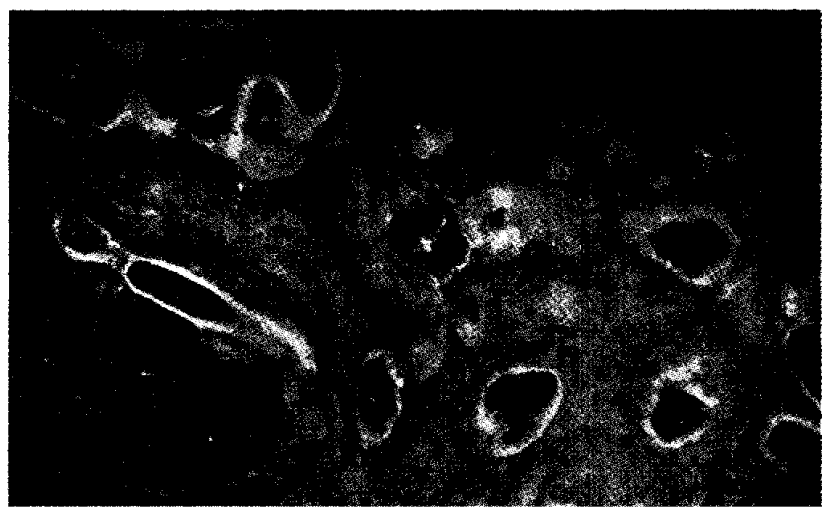

‘j !': 7

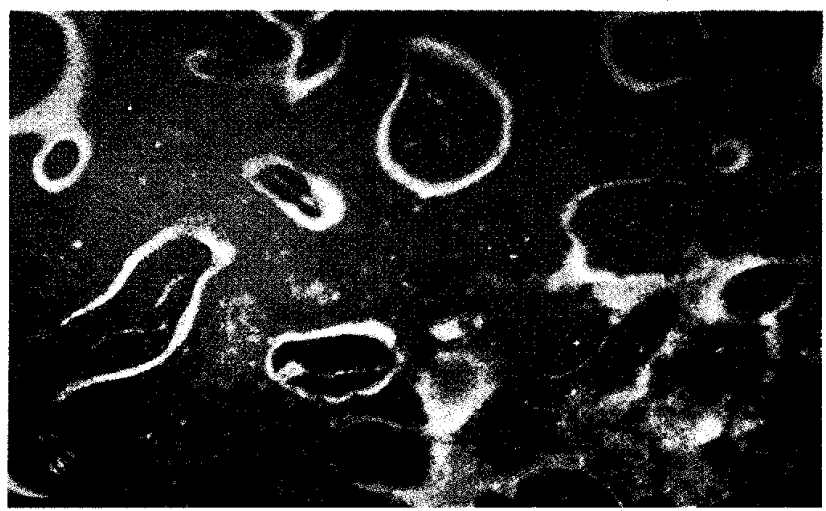

I' 8 


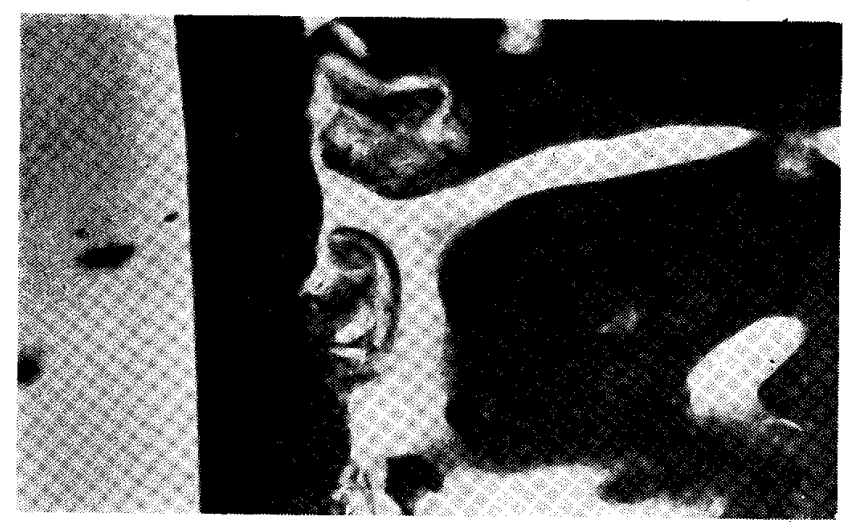

等真 9

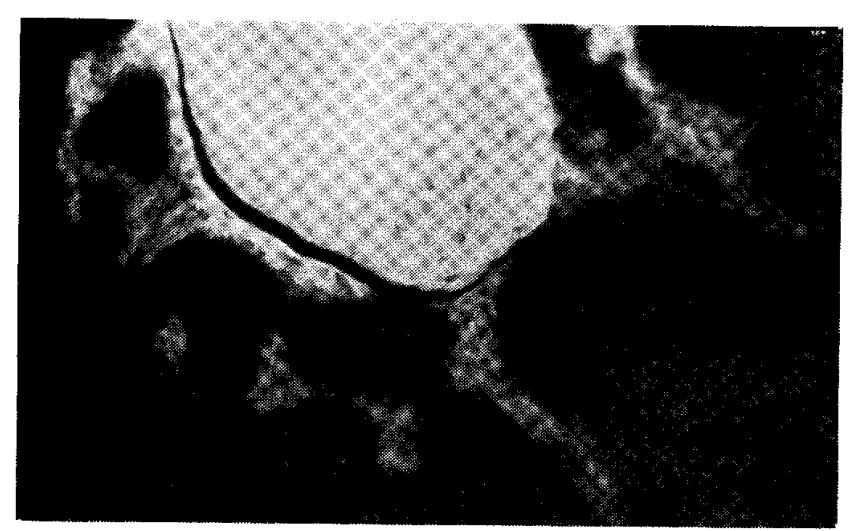

it 10

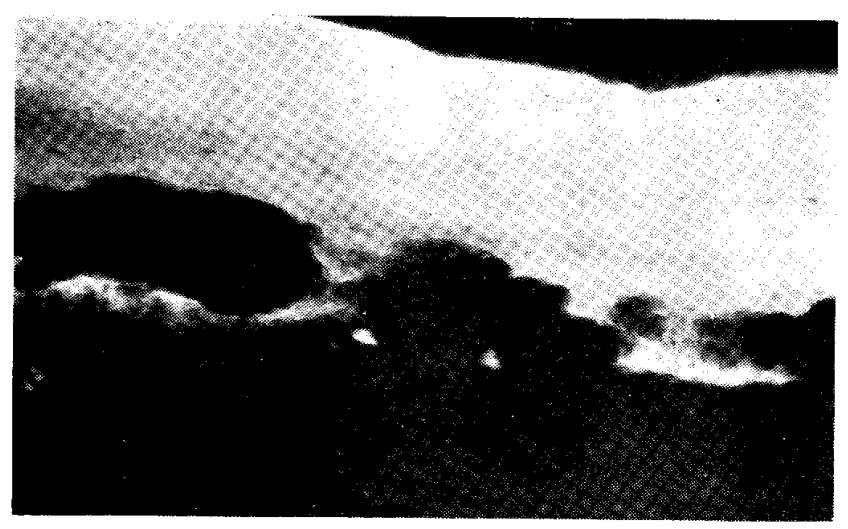

独 11

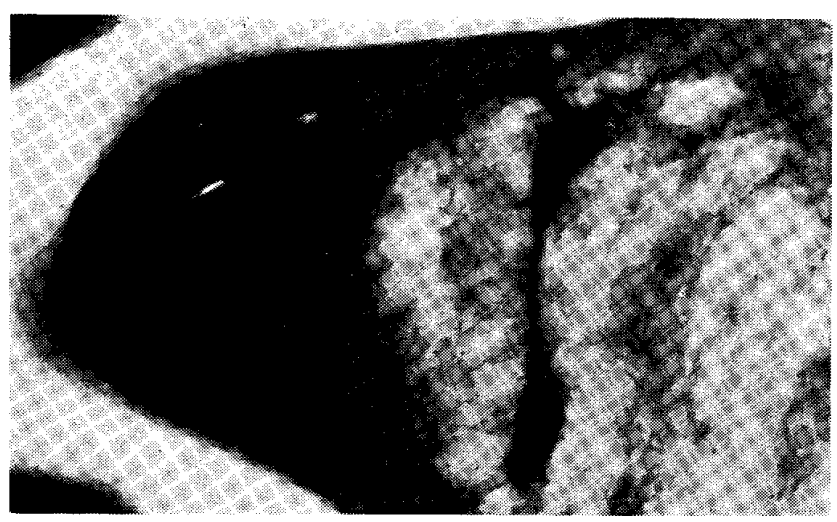

点 12

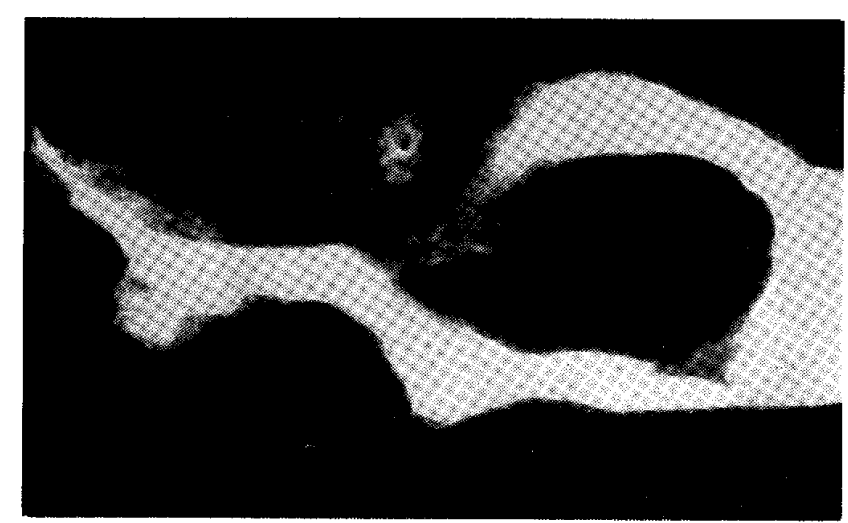

写 真 13

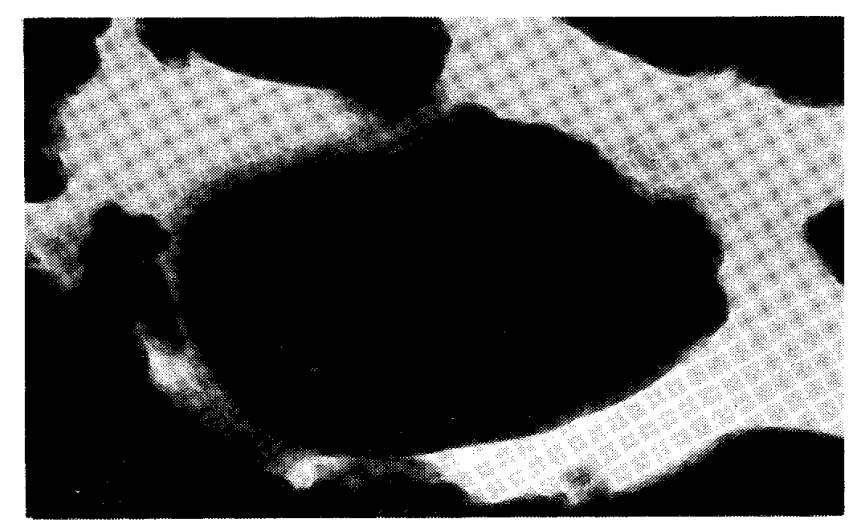

点 14

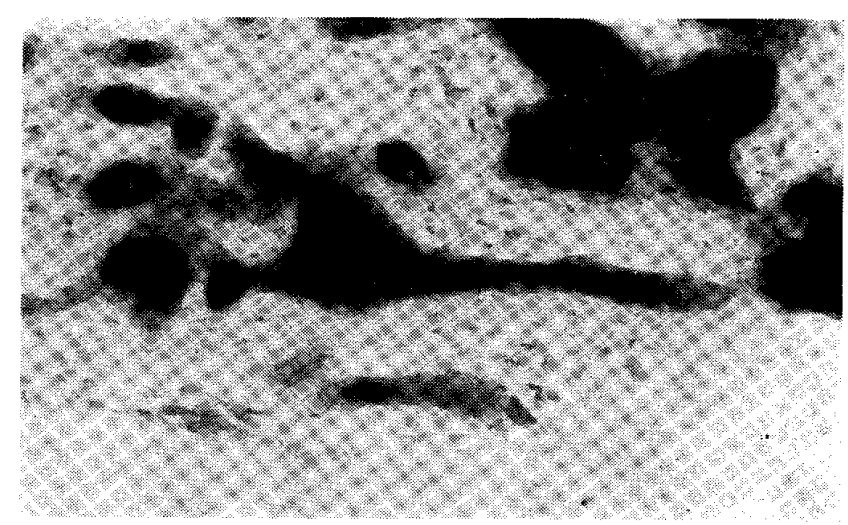

㝍拲 15

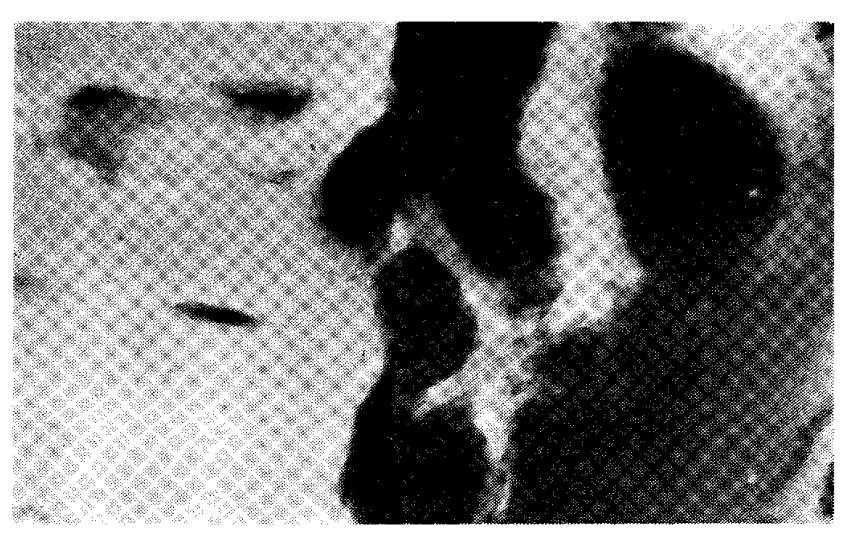

写真 16 


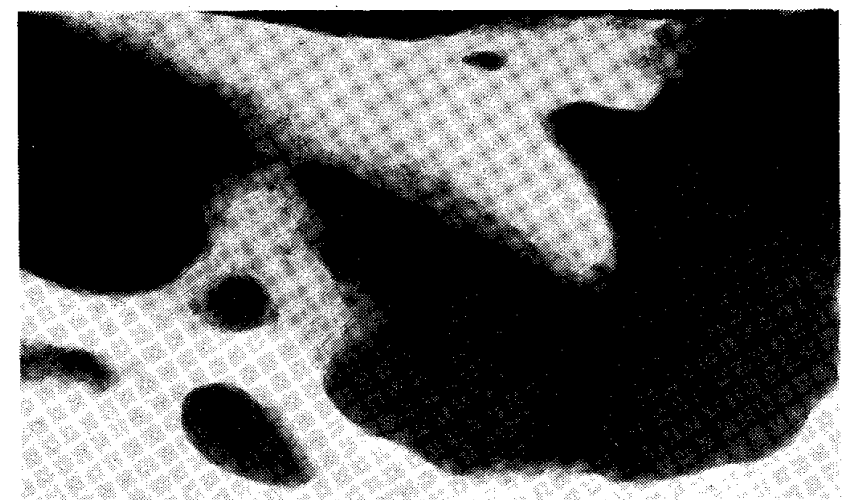

等 真 17

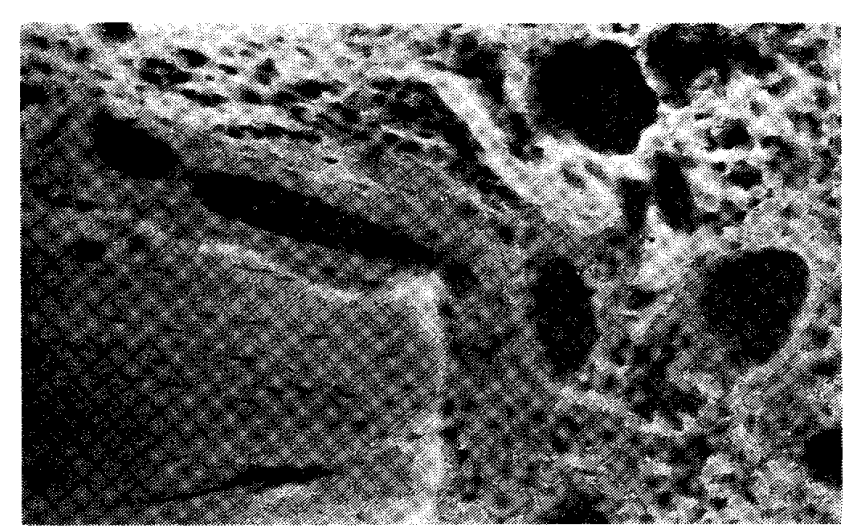

写真 18

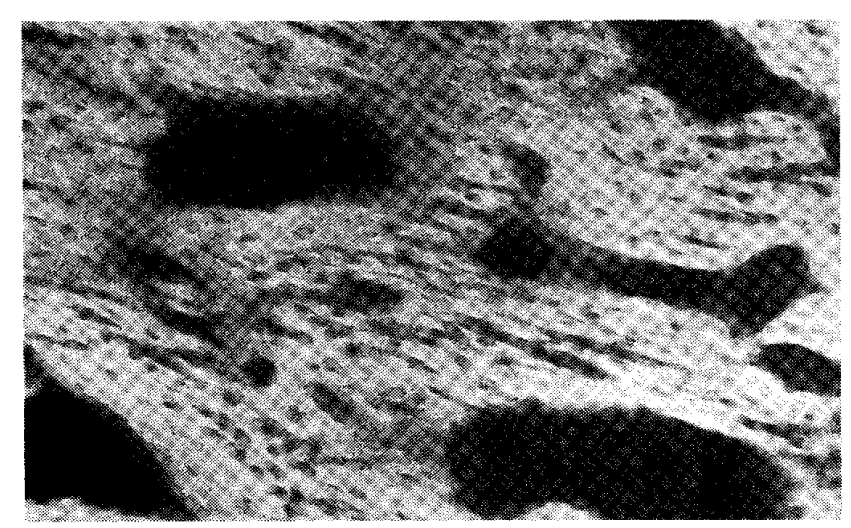

写真 19

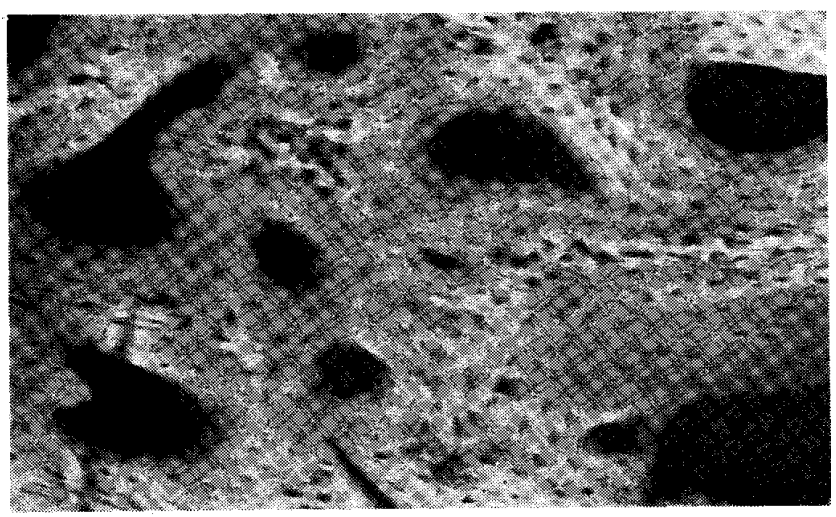

写 真 20

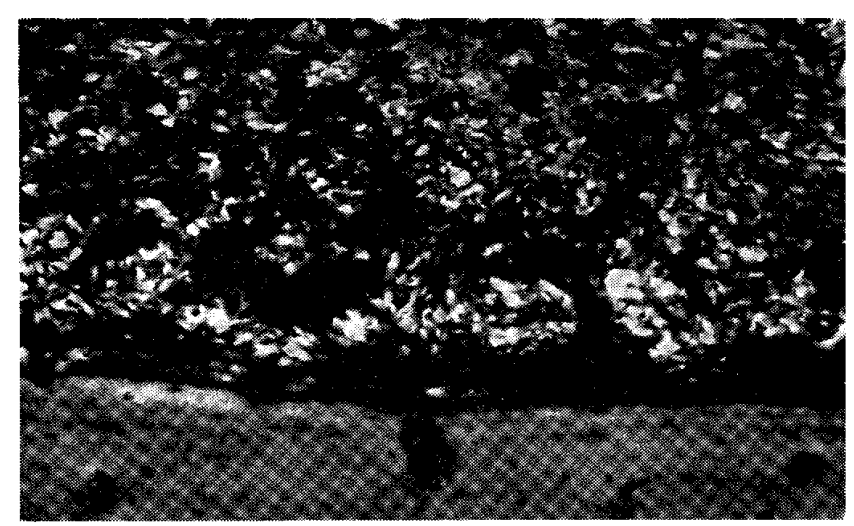

真 21

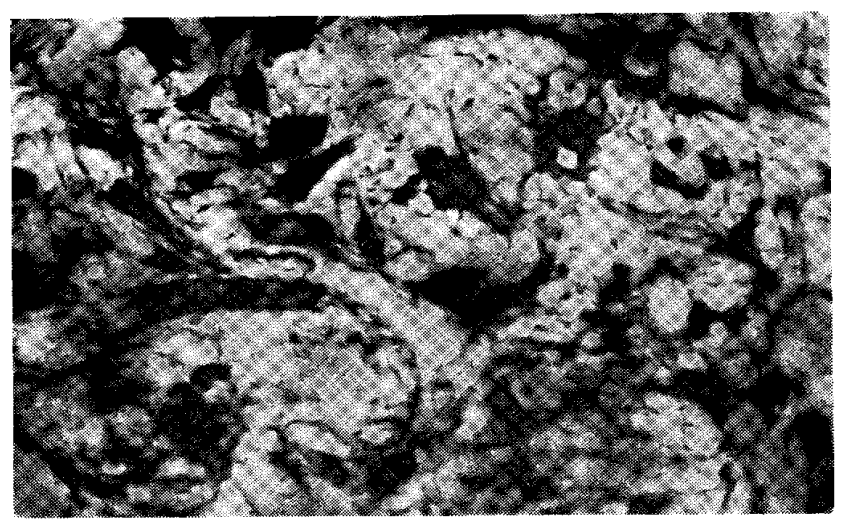

写 真 22

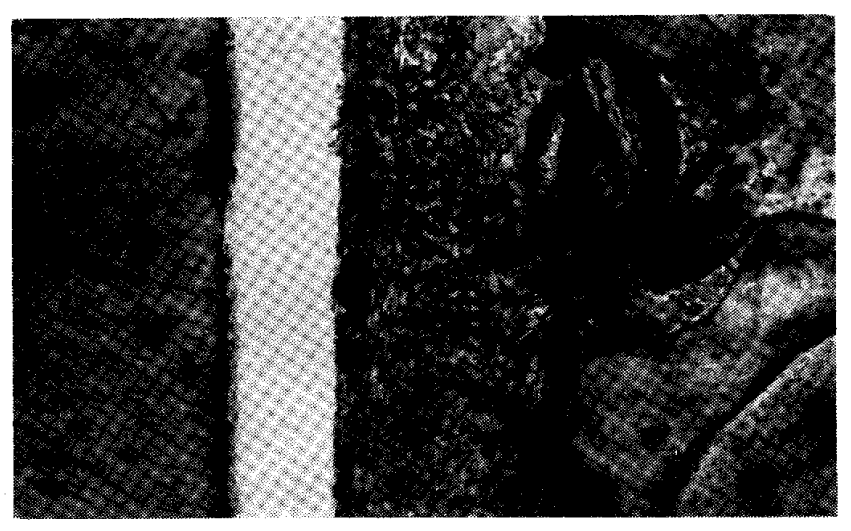

乌真 23

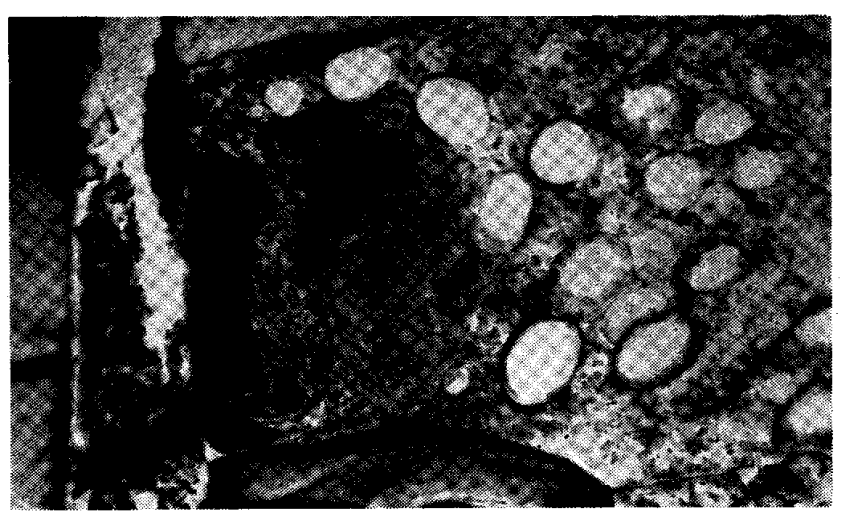

写 真 24 


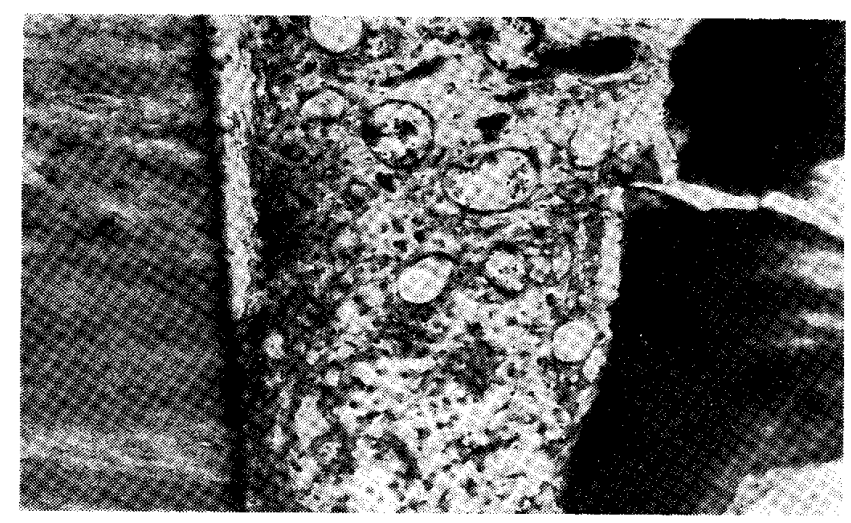

写真 25

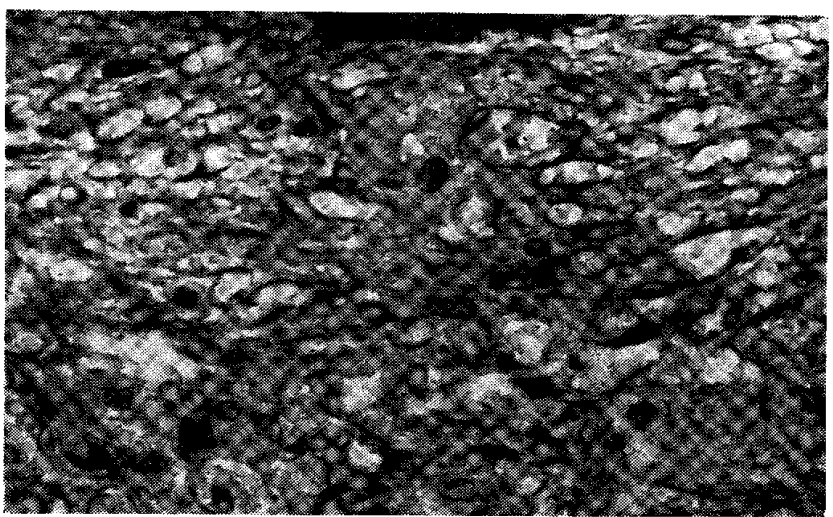

写 真 26

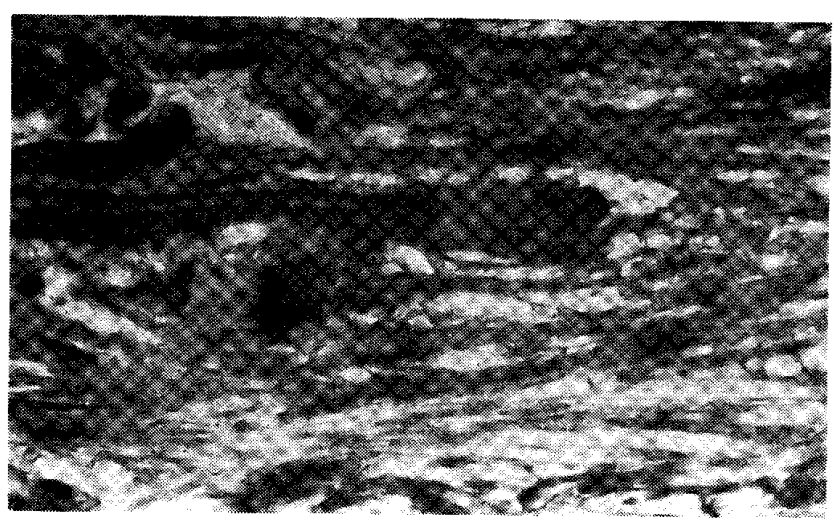

写真 27

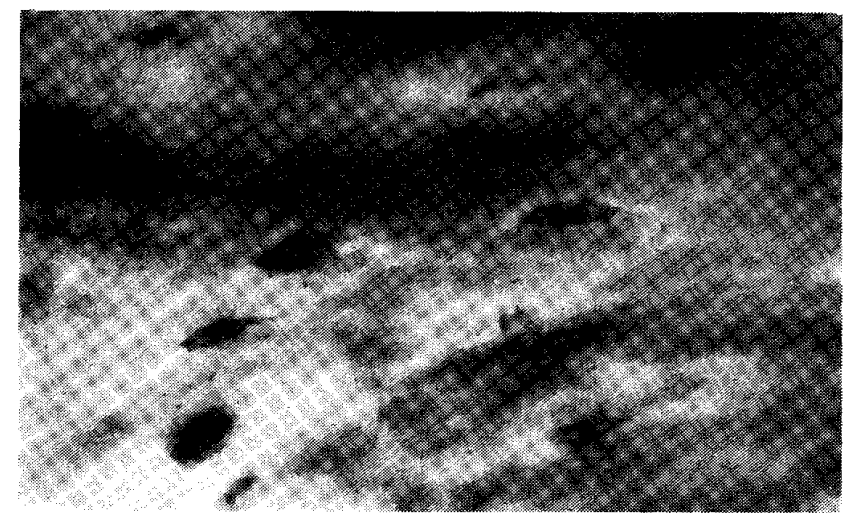

写真 28

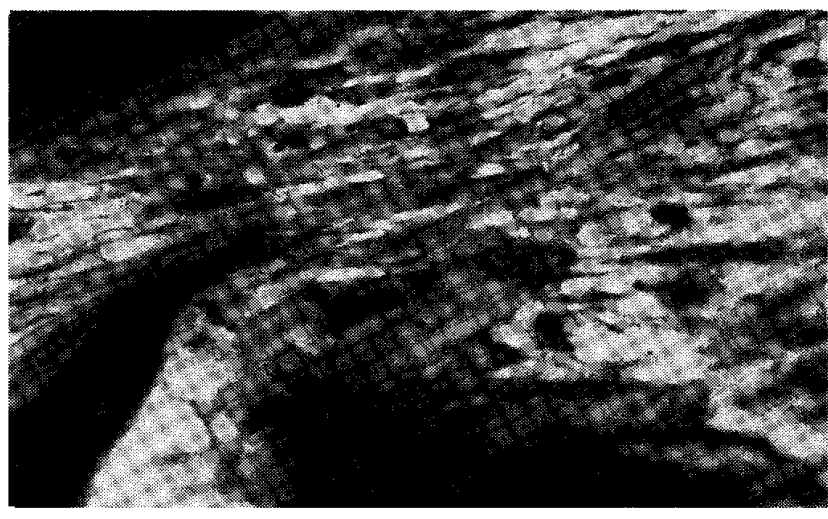

写 真 29

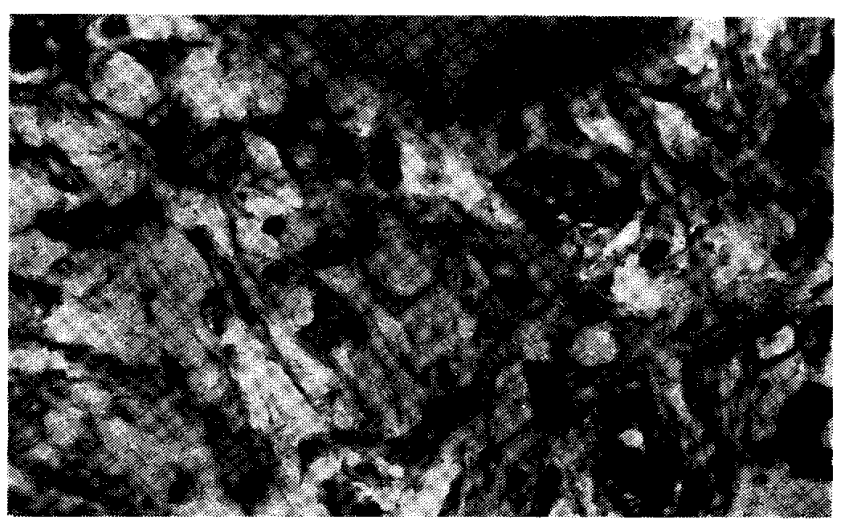

写 真 30

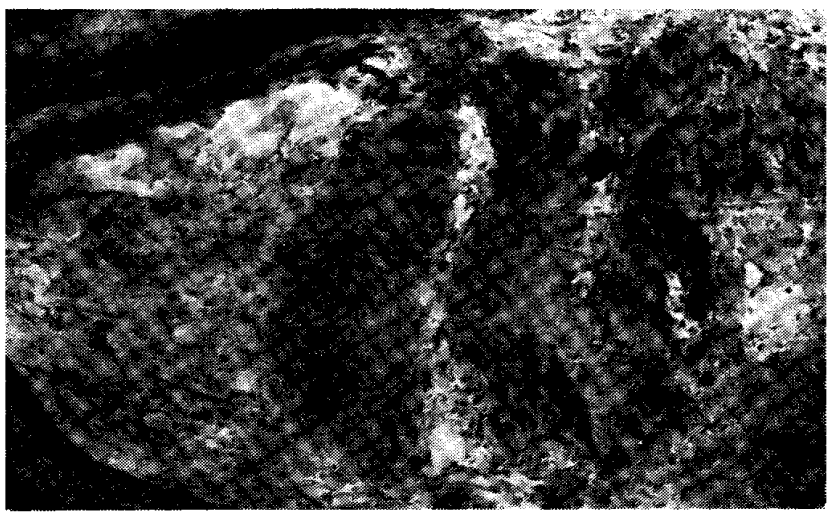

写真 31

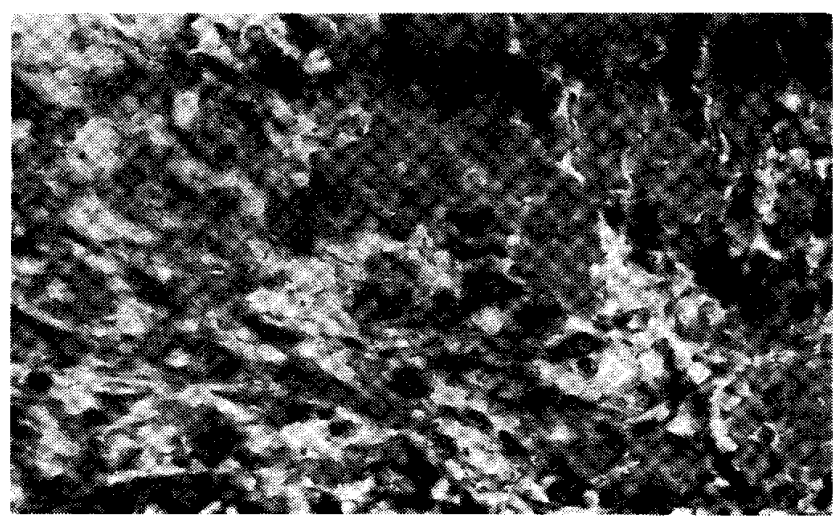

写真 32 


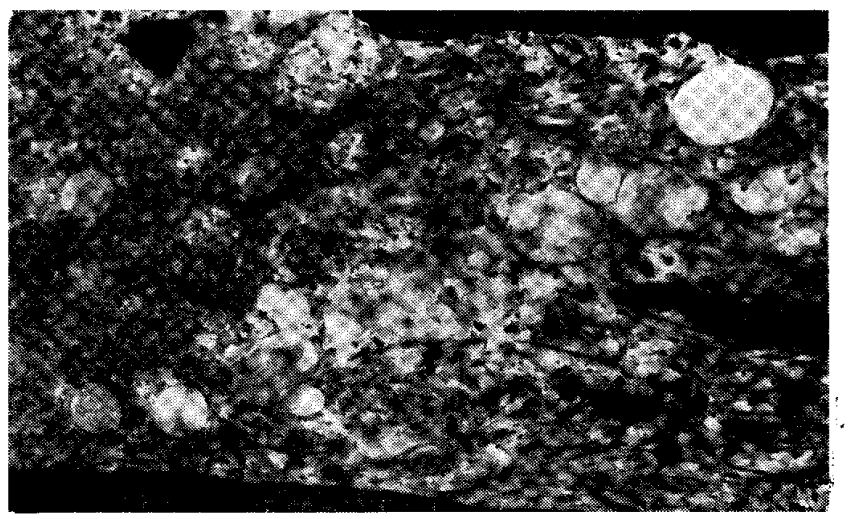

写真 33

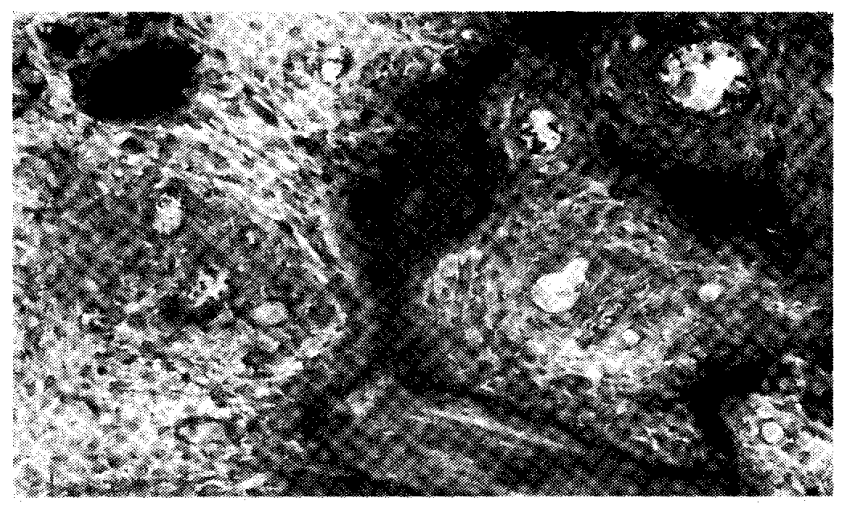

写真 34

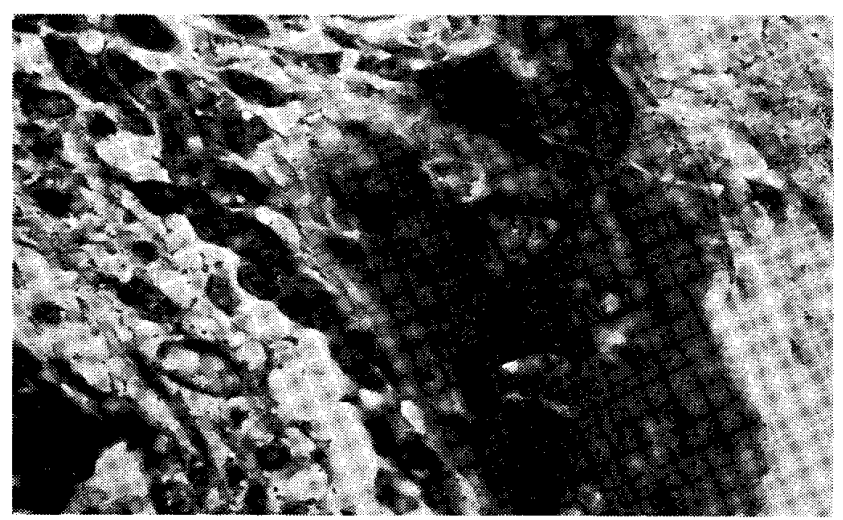

写 真 35

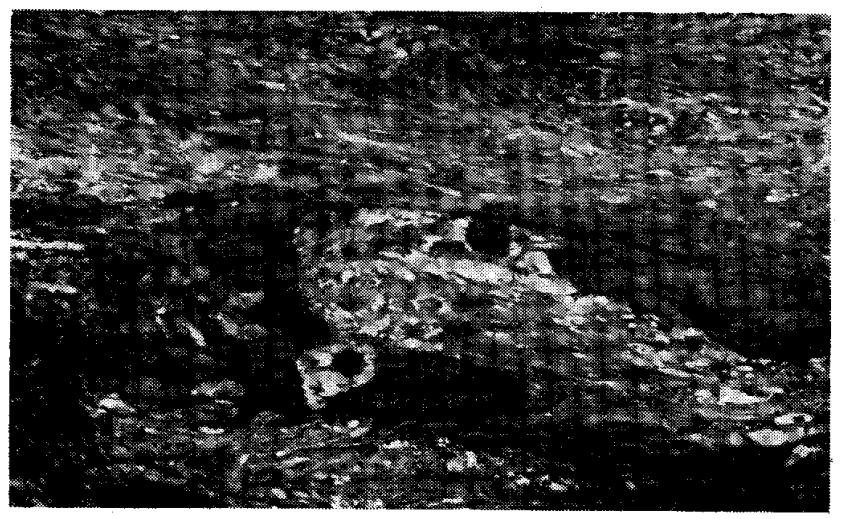

写貲 36

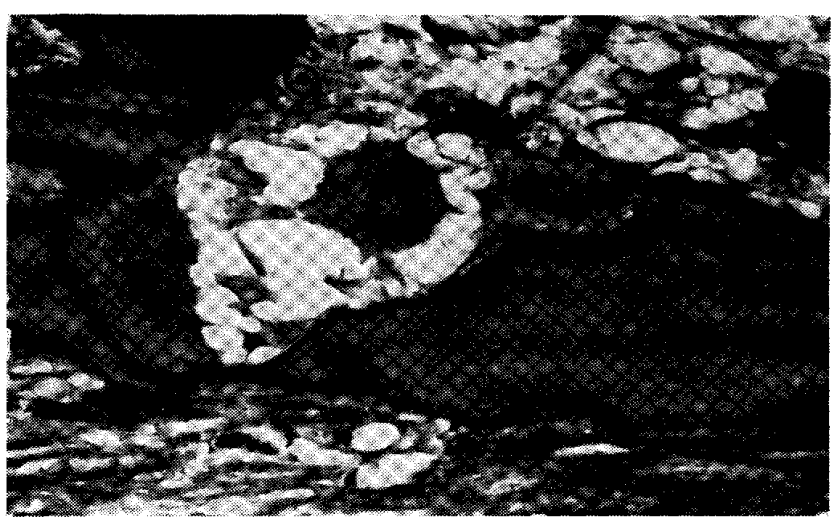

等真 37

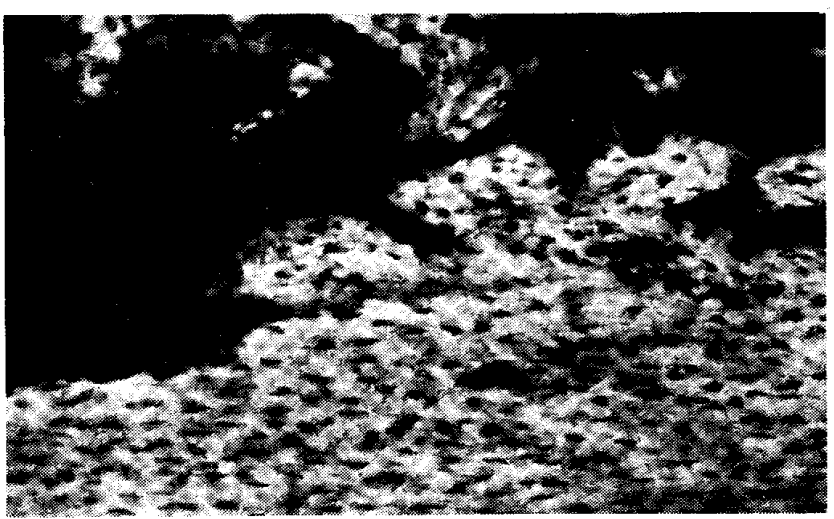

写真 38

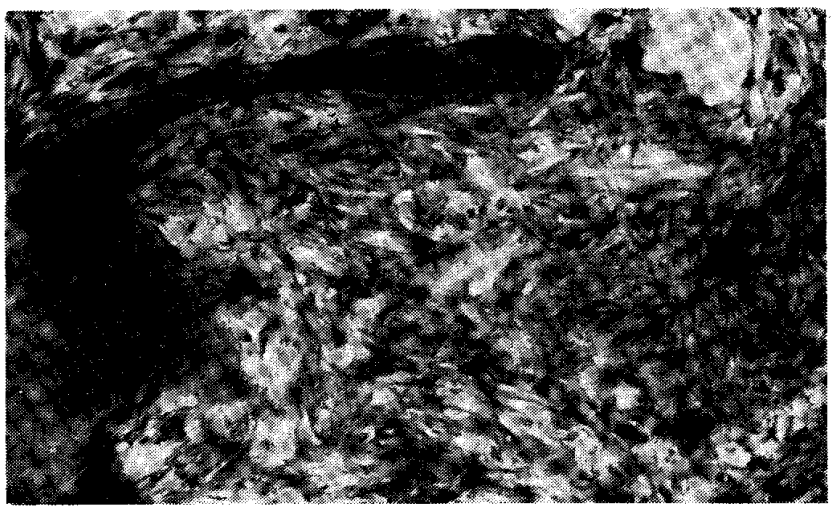

写 真 39

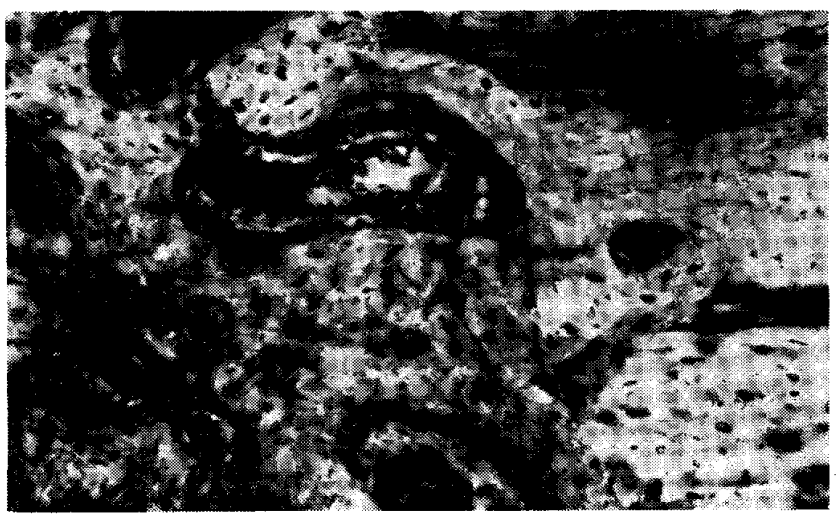

写 真 40 


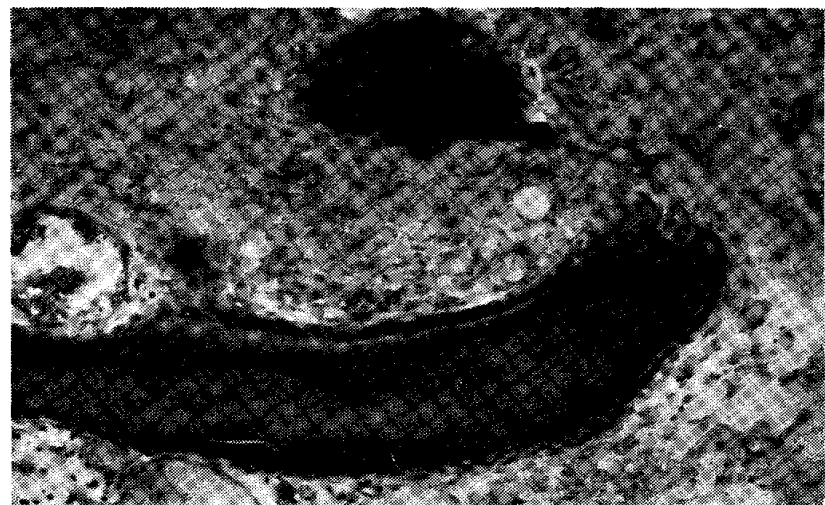

军真 41

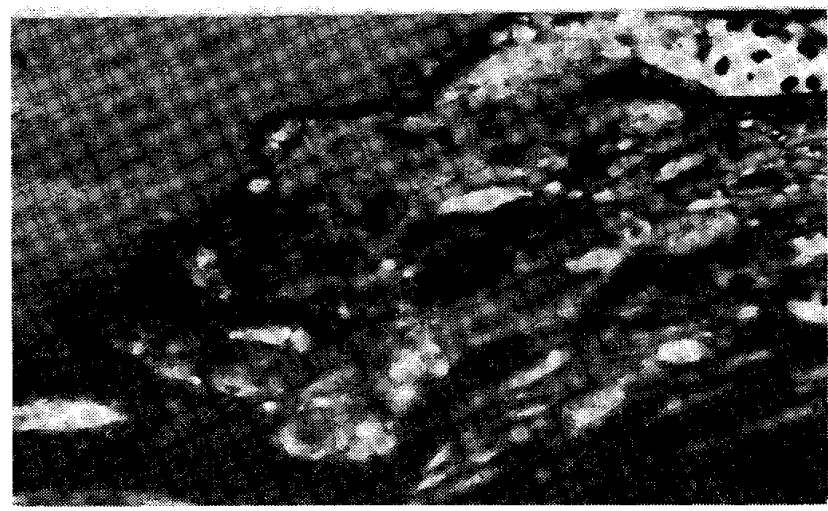

写真 42

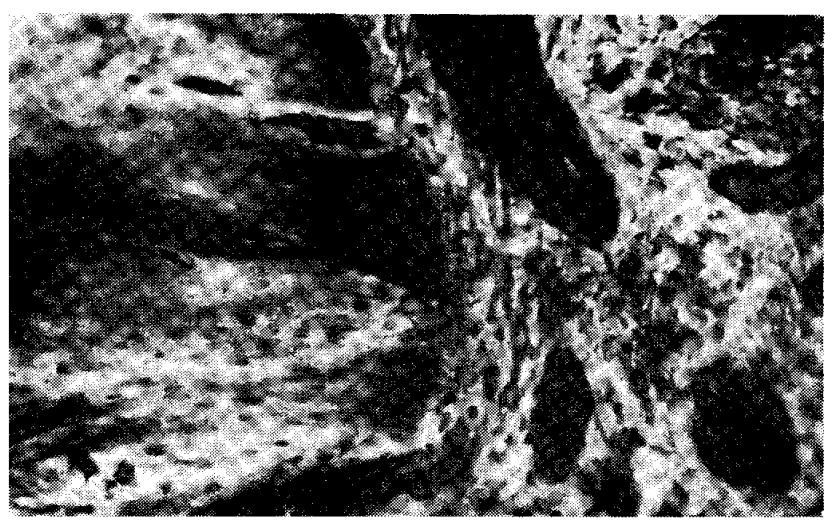

写 真 43

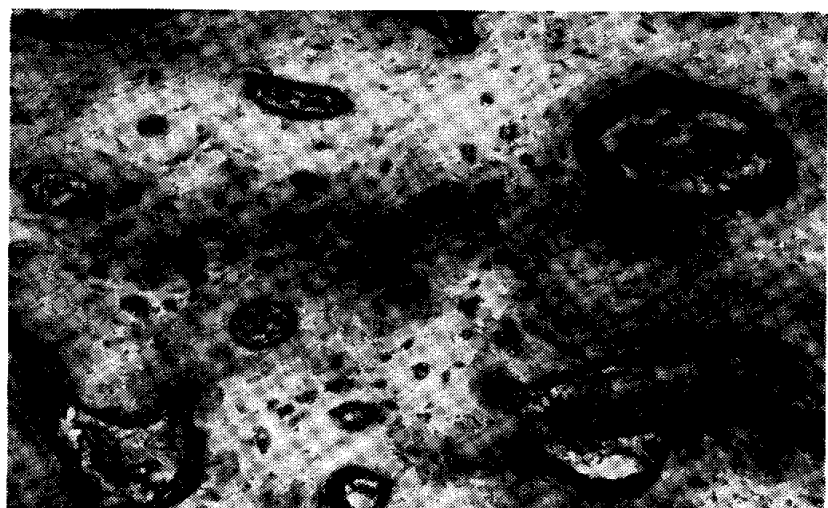

写 真 44

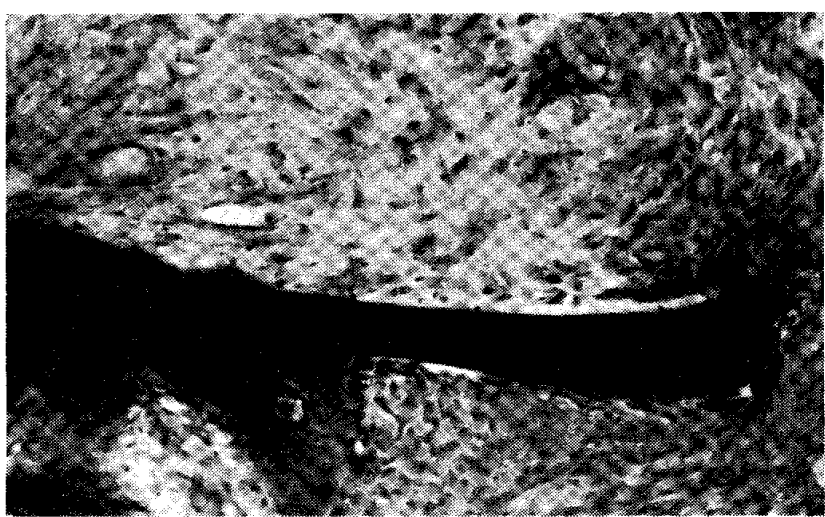

写 真 45

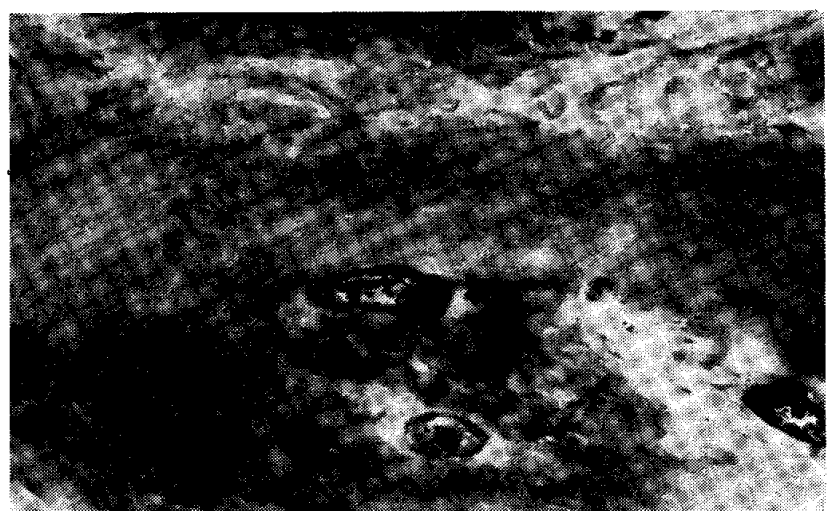

写 真 46 